\title{
Intracluster Sulphur Dioxide Oxidation by Sodium Chlorite Anions: A Mass Spectrometric Study
}

\author{
Chiara Salvitti *(D), Federico Pepi (D), Anna Troiani *(D) and Giulia de Petris \\ Dipartimento di Chimica e Tecnologie del Farmaco, "Sapienza" University of Rome, 00185 Rome, Italy; \\ federico.pepi@uniroma1.it (F.P.); giulia.depetris@uniroma1.it (G.d.P.) \\ * Correspondence: chiara.salvitti@uniroma1.it (C.S.); anna.troiani@uniroma1.it (A.T.)
}

check for updates

Citation: Salvitti, C.; Pepi, F.; Troiani, A.; de Petris, G. Intracluster Sulphur Dioxide Oxidation by Sodium Chlorite Anions: A Mass Spectrometric Study. Molecules 2021, 26,7114. https://doi.org/10.3390/ molecules26237114

Academic Editor: Giorgio S. Senesi

Received: 3 November 2021

Accepted: 22 November 2021

Published: 24 November 2021

Publisher's Note: MDPI stays neutral with regard to jurisdictional claims in published maps and institutional affiliations.

Copyright: (c) 2021 by the authors. Licensee MDPI, Basel, Switzerland. This article is an open access article distributed under the terms and conditions of the Creative Commons Attribution (CC BY) license (https:// creativecommons.org/licenses/by/ $4.0 /)$.
Abstract: The reactivity of $\left[\mathrm{NaL} \cdot \mathrm{ClO}_{2}\right]^{-}$cluster anions $\left(\mathrm{L}=\mathrm{ClO}_{\mathrm{x}}{ }^{-} ; \mathrm{x}=0-3\right)$ with sulphur dioxide has been investigated in the gas phase by ion-molecule reaction experiments (IMR) performed in an in-house modified Ion Trap mass spectrometer (IT-MS). The kinetic analysis revealed that $\mathrm{SO}_{2}$ is efficiently oxidised by oxygen-atom (OAT), oxygen-ion (OIT) and double oxygen transfer (DOT) reactions. The main difference from the previously investigated free reactive $\mathrm{ClO}_{2}{ }^{-}$is the occurrence of intracluster OIT and DOT processes, which are mediated by the different ligands of the chlorite anion. This gas-phase study highlights the importance of studying the intrinsic properties of simple reacting species, with the aim of elucidating the elementary steps of complex processes occurring in solution, such as the oxidation of sulphur dioxide.

Keywords: cluster reactivity; sulphur dioxide; sodium chlorite; mass spectrometry; ion-molecule reactions; oxidation reactions

\section{Introduction}

Pollution and other environmental issues are typically associated with the atmospheric emissions of exhaust flue gases produced by power plants and industries [1]. Different technologies, collectively known as flue gas cleaning processes, attempt to mitigate the release of greenhouse gases deriving from the burning of coal to generate electrical power [2]. Most efforts in this field are aimed at planning pollutant-control strategies to reduce sulphur dioxide which is referred to as the main precursor of acid rainfalls and atmospheric particulate [3-5]. To this end, the European Union established the 2016/2284/UE Regulation that intends to progressively reduce $\mathrm{SO}_{2}$ emissions until 2029 and for the next few years [6].

Among the flue gas desulphurization (FGD) methods, the wet scrubbing system is a low-cost and simple technology based on the reaction between $\mathrm{SO}_{2}$ and an alkaline sorbent, typically limestone [7-9]. Although engineers mostly design separate air-cleaning devices for individual gas emission removal, the search for multi-pollutant control systems would reduce the need for large installation areas and operation costs [10]. To this end, sodium chlorite $\left(\mathrm{NaClO}_{2}\right)$ is one of the most effective reagents for the simultaneous removal of oxides of sulphur $\left(\mathrm{SO}_{\mathrm{x}}\right)$ and nitrogen $\left(\mathrm{NO}_{\mathrm{x}}\right)$ [11]. The addition of this compound to seawater solution has been recently exploited to improve the elimination of $\mathrm{SO}_{2}$ and favour the development of environmentally friendly seawater-based FGD [12].

The strong oxidative properties of $\mathrm{NaClO}_{2}$ allows the conversion of sulphites $\left(\mathrm{SO}_{3}{ }^{2-}\right)$ produced by $\mathrm{SO}_{2}$ absorption to the harmless sulphates $\left(\mathrm{SO}_{4}{ }^{2-}\right)$ that are easily solubilized in water and thus removed $[13,14]$. Nevertheless, many factors can affect the outcome of the scrubbing process (e.g., $\mathrm{pH}$, temperature, oxidant concentration, oxidant/gas contact time, volumetric gas, liquid flow rates) and the influence of these parameters has to be carefully evaluated in the design of the operating systems [15-17]. For instance, solution salinity is known to increase $\mathrm{SO}_{2}$ absorption efficiency, and under alkaline conditions needed for $\mathrm{SO}_{2} / \mathrm{SO}_{3}{ }^{-}$conversion, the occurrence of a gas-solid interface reaction between $\mathrm{SO}_{2}$ and $\mathrm{NaClO}_{2}$ gives rise to the formation of $\mathrm{Cl}^{\circ}, \mathrm{ClO}^{\circ}$ and $\mathrm{OClO}^{\circ}$ chlorinated species which may 
enhance the concomitant $\mathrm{NO}$ oxidation in multi-pollutant removal plants $[18,19]$. On the other side, the above-mentioned factors can contribute to masking the intrinsic reactivity of $\mathrm{NaClO}_{2}$ towards sulphur dioxide preventing the elucidation of the mechanistic details that lead to the oxidation of $\mathrm{SO}_{2}$ and the formation of collateral products.

A successful strategy to avoid solution interfering effects and investigate the chemical processes at a strictly molecular level consists in performing gas-phase studies by mass spectrometry [20-26]. This technique is one of the most routinely employed for analytical purposes in a plethora of research fields spanning, inter alia, from foods and drugs to biology [27-34] or from geology to atmospheric chemistry [35-39]. Less well known is the use of mass spectrometry in fields such as catalysis, nevertheless, in the last years, mass spectrometry has been widely employed to assess the elementary steps of a chemical transformation by unravelling mechanistic pathways and elucidating the factors which affect the reaction outcome [40-46]. Accordingly, ion-molecule reaction (IMR) experiments were largely intended to investigate the reactivity of ionic reagents generated at their ground state towards neutral species under single-collision conditions. The gas-phase reaction of free $\mathrm{ClO}^{-}$and $\mathrm{ClO}_{2}{ }^{-}$anions towards $\mathrm{SO}_{2}$ has actually provided important information on the intrinsic properties of naked chlorite leading to the oxidation of sulphur dioxide to $\mathrm{SO}_{3}, \mathrm{SO}_{3} \cdot-$ and $\mathrm{SO}_{4} \cdot{ }^{\cdot-}$, with the concomitant formation of the chlorinated species $\mathrm{ClO}^{-}, \mathrm{ClO}^{\circ}$, and $\mathrm{Cl}^{-}$[47]. These reaction channels, respectively referred to as oxygen-atom (OAT), oxygen-ion (OIT), and double oxygen transfer (DOT), may represent simplified models of large-scale reactions occurring in the atmosphere or involved in the flue-gas desulphurization processes.

In addition, electrospray ionization mass spectrometry has been long-time devoted to the study of salt speciation [48-50] showing its capability in controlling the size and charge of cluster ions. As a result, ionic clusters can be considered miniaturized systems to investigate the intrinsic features of matter aggregation phenomena [51,52]. Accordingly, the study of the gas-phase reactions of $\mathrm{SO}_{2}$ with positive and negative carbonate cluster ions contributed to highlighting the major role of the charge in the kinetics of smallest clusters, as well as the different reactivity when charged cluster are ligated to a $\mathrm{NaOH}$ molecule [53]. Indeed, a point-charge ligand can generate oriented external electric fields able to change thermodynamics and kinetics of a gas-phase thermal process by controlling the reaction mechanism, efficiencies, and product distribution [54-56].

Continuing with our studies focused on the chemistry of sulphur dioxide [57-62], here we report on the gas-phase reactivity of negatively charged chlorite cluster ions, $\left[\mathrm{NaL} \cdot \mathrm{ClO}_{2}\right]^{-}\left(\mathrm{L}=\mathrm{ClO}_{\mathrm{x}}{ }^{-}\right.$with $\left.x=0-3\right)$, towards $\mathrm{SO}_{2}$ investigated by ion-molecule reaction experiments. In this way, the effect of the ligation of a neutral molecule to $\mathrm{ClO}_{2}{ }^{-}$that changes the ion size and charge distribution of the cluster has been evaluated based on the known reactivity of naked $\mathrm{ClO}_{2}{ }^{-}$species with $\mathrm{SO}_{2}$.

\section{Results and Discussion}

Oxo-halogenated ions investigated in this work were generated by the negative electrospray ionization of $\mathrm{NaClO}_{2}$ solutions typically yielding a series of singly-charged cluster ions in which $\mathrm{NaClO}_{2}$ is clustered to the $\mathrm{ClO}_{2}{ }^{-}$anion to form aggregates resembling the general formula $\left[\left(\mathrm{NaClO}_{2}\right)_{\mathrm{n}} \cdot \mathrm{ClO}_{2}\right]^{-}, n$ varying from 1 to 4 in the $m / z$ range 100-500 (Figure S1). Aggregation phenomena are indeed characteristic of electrosprayed saline compounds [49] and are influenced by the solute concentrations and source parameters [53]. Furthermore, the electric field applied between the capillary and the skimmer plate accounts for the occurrence of electrochemical reactions at the conductive contact-solution interface near the ES emitter [63]. The detection of $\mathrm{ClO}_{x}{ }^{-}(x=0,1,3)$ anions in addition to the $\mathrm{ClO}_{2}{ }^{-}$parent species suggests the effective occurrence of in-source redox processes. For $x=1$ and 3, the corresponding $\mathrm{ClO}^{-}$and $\mathrm{ClO}_{3}{ }^{-}$anions do not undergo significant aggregation phenomena. On the contrary, $\mathrm{Cl}^{-}$anions promote aggregation with $\mathrm{NaClO}_{2}$ to form $\left[\left(\mathrm{NaClO}_{2}\right)_{\mathrm{n}} \cdot \mathrm{Cl}\right]^{-}$ions $(n=1-5)$, and mixed clusters of general formula $\left[\mathrm{Na}_{\mathrm{x}} \mathrm{Cl}_{\mathrm{y}} \mathrm{O}_{\mathrm{z}}\right]^{-}$ were also identified as minor species, as shown in the Supplementary Materials (Figure S1). 
The simplest $\mathrm{ClO}_{2}{ }^{-}$clusters for $n=1$ were found at $m / z 125$ and 157 and respectively attributed to the ${ }^{35}$ chlorine isotopologue of $\left[\mathrm{NaCl} \cdot \mathrm{ClO}_{2}\right]^{-}$and $\left[\mathrm{NaClO}_{2} \cdot \mathrm{ClO}_{2}\right]^{-}$species. The assignment was based on the distinctive ${ }^{35 / 37} \mathrm{Cl}$ isotope pattern and on the corresponding collision-induced dissociation (CID) mass spectra. The ion $\left[\mathrm{Na}^{35} \mathrm{Cl}^{3} \cdot{ }^{35} \mathrm{ClO}_{2}\right]^{-}$ at $m / z 125$ predominantly fragments by losing a $\mathrm{Na}^{35} \mathrm{Cl}$ neutral counterpart giving rise to the ${ }^{35} \mathrm{ClO}_{2}{ }^{-}$daughter ion at $m / z 67$ (Figure 1a). The gas-phase decomposition of the corresponding ${ }^{35 / 37} \mathrm{Cl}$ isotopomer $(\mathrm{m} / z 127)$ predictably leads to the formation of an equal ratio of ${ }^{35} \mathrm{ClO}_{2}{ }^{-}$and ${ }^{37} \mathrm{ClO}_{2}{ }^{-}$fragments at $m / z 67$ and 69 , respectively (Figure $1 \mathrm{~b}$ ). The parent ion can be therefore described as a complex of the type $\left[\mathrm{Cl} \cdot \mathrm{Na} \cdot \mathrm{ClO}_{2}\right]^{-}$in which both the chloride $\left(\mathrm{Cl}^{-}\right)$and chlorite $\left(\mathrm{ClO}_{2}{ }^{-}\right)$anions are coordinated to the sodium cation $\left(\mathrm{Na}^{+}\right)$. In particular, the chlorite moiety is reasonably consistent with an $\mathrm{OClO}^{-}$species rather than with the more stable $\mathrm{ClOO}^{-}$isomer, the presence of which can be excluded considering the structure of the precursor salt, $\mathrm{NaClO}_{2}$, and the high energy barrier to the isomerization, calculated to be $51.1 \mathrm{kcal} \cdot \mathrm{mol}^{-1}$, [47] which cannot be overcome by the ions during the ionization process.
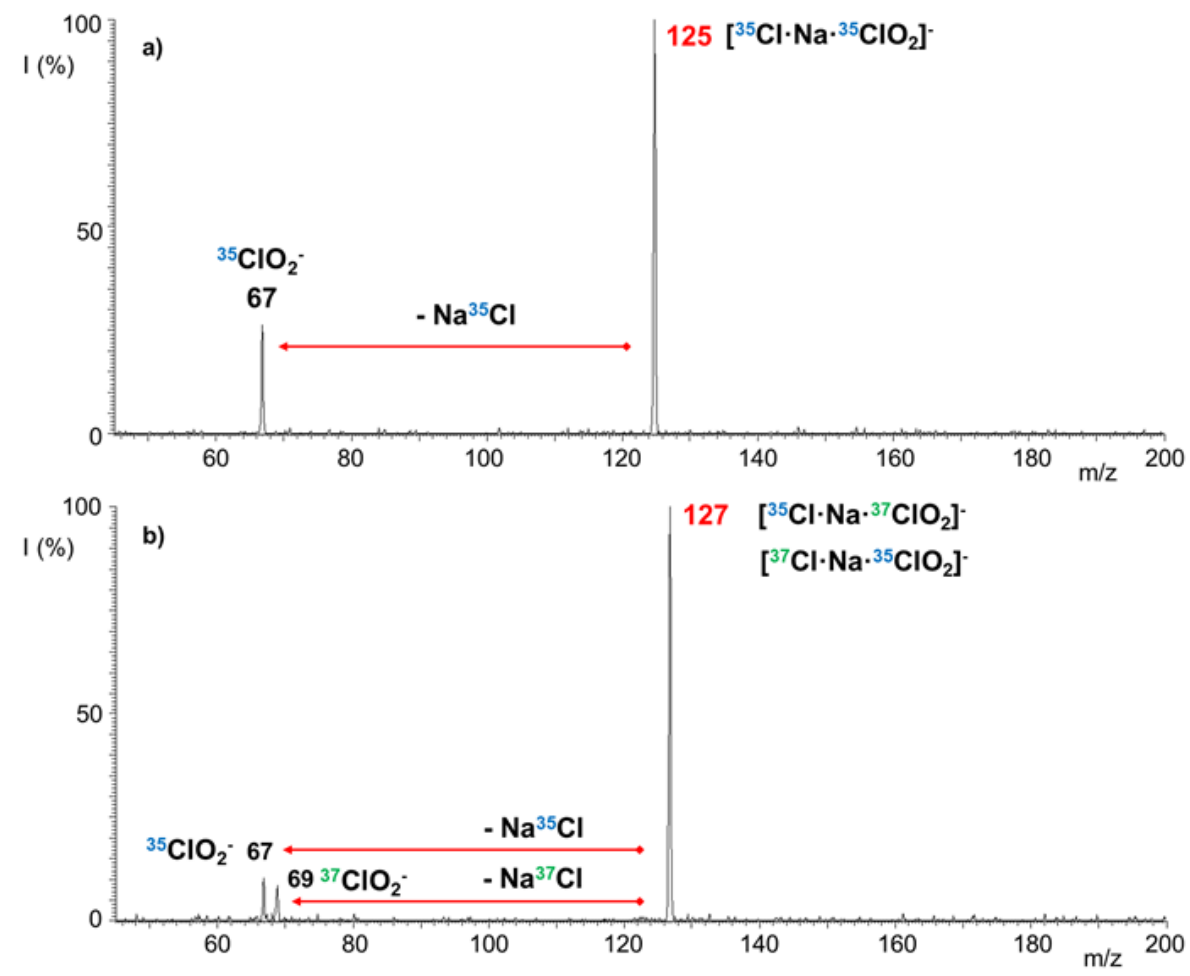

Figure 1. ESI-(-) CID mass spectra of the isolated (a) $\left[\mathrm{Na}^{35} \mathrm{Cl}^{35} \mathrm{ClO}_{2}\right]^{-}$at $\mathrm{m} / z 125$ and (b) $\left[\mathrm{Na}^{35} \mathrm{Cl} \cdot{ }^{37} \mathrm{ClO}_{2}\right]^{-}$and $\left[\mathrm{Na}^{37} \mathrm{Cl}^{35} \mathrm{ClO}_{2}\right]^{-}$at $m / z 127$.

Similarly, the CID mass spectrum of the ionic species $\left[\mathrm{Na}^{35} \mathrm{ClO}_{2} \cdot{ }^{35} \mathrm{ClO}_{2}\right]^{-}$at $m / z 157$ shows the only daughter ion ${ }^{35} \mathrm{ClO}_{2}{ }^{-}$at $m / z 67$, arising from the loss of a $\mathrm{NaClO}_{2}$ neutral counterpart (Figure 2a). Accordingly, the gas-phase decomposition of the isotopomer at $m / z 159$ leads to the formation of an equal ratio of ${ }^{35} \mathrm{ClO}_{2}{ }^{-}$and ${ }^{37} \mathrm{ClO}_{2}{ }^{-}$fragment ions at $m / z 67$ and 69 (Figure 2b), accounting for the symmetrical complex $\left[\mathrm{ClO}_{2} \cdot \mathrm{Na}^{-\mathrm{ClO}_{2}}\right]^{-}$. 


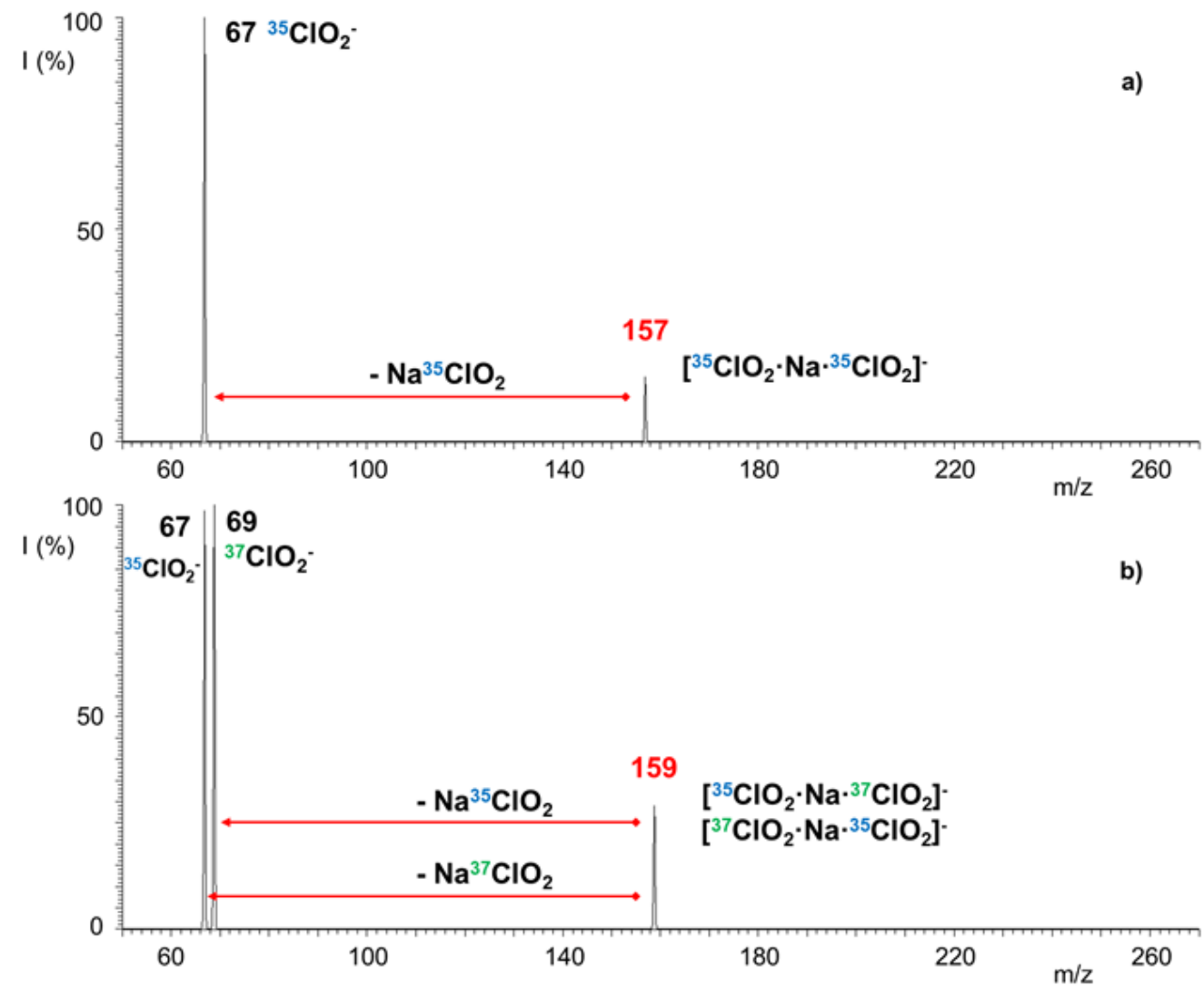

Figure 2. ESI-(-) CID mass spectra of the isolated (a) $\left[\mathrm{Na}^{35} \mathrm{ClO}_{2} \cdot{ }^{35} \mathrm{ClO}_{2}\right]^{-}$at $\mathrm{m} / \mathrm{z} 157$ and (b) $\left[\mathrm{Na}^{35} \mathrm{ClO}_{2} \cdot{ }^{37} \mathrm{ClO}_{2}\right]^{-}$and $\left[\mathrm{Na}^{37} \mathrm{ClO}_{2} \cdot{ }^{35} \mathrm{ClO}_{2}\right]^{-}$at $m / z 159$.

Each ionic species described above was in turn isolated into the ion trap and exposed to unreactive gas $(\mathrm{He})$ over long accumulation times. Since no remarkable signal loss occurred, these ions can be considered rather stable gaseous chlorine-based aggregates. When reacted with $\mathrm{SO}_{2}$, they showed a noteworthy reactivity. In the following, the reactivity of selected cluster ions, $\left[\mathrm{Cl} \cdot \mathrm{Na} \cdot \mathrm{ClO}_{2}\right]^{-}$and $\left[\mathrm{ClO}_{2} \cdot \mathrm{Na} \cdot \mathrm{ClO}_{2}\right]^{-}$, will be described in depth, starting from the simplest $\left[\mathrm{Cl} \cdot \mathrm{Na} \cdot \mathrm{ClO}_{2}\right]^{-}$. At the occurrence, the formula of the reacting species is written with the sodium cation in the centre, to highlight the reactive anionic units. Similar to the reactions observed with the non-clustered $\mathrm{ClO}_{2}{ }^{-}$ions [47], both $\left[\mathrm{Cl} \cdot \mathrm{Na} \cdot \mathrm{ClO}_{2}\right]^{-}$and $\left[\mathrm{ClO}_{2} \cdot \mathrm{Na} \cdot \mathrm{ClO}_{2}\right]^{-}$cluster ions promote oxygen-atom transfer (OAT), oxygen-ion transfer (OIT), and double oxygen transfer (DOT) towards $\mathrm{SO}_{2}$. The main difference with the free $\mathrm{ClO}_{2}{ }^{-}$is that when $\mathrm{SO}_{2}$ is oxidised, the oxidised products predominantly remain in the cluster and are not released as free species. Accordingly, the whole mechanistic picture of the reactions between $\left[\mathrm{Cl} \cdot \mathrm{Na} \cdot \mathrm{ClO}_{2}\right]^{-}$and $\left[\mathrm{ClO}_{2} \cdot \mathrm{Na} \cdot \mathrm{ClO}_{2}\right]^{-}$anions towards $\mathrm{SO}_{2}$ was outlined by identifying direct and consecutive pathways, measuring the rate constants for each reaction channel, and structurally characterizing the ionic products by CID experiments.

\subsection{Reactivity of $\left[\mathrm{Cl} \cdot \mathrm{Na} \cdot \mathrm{ClO}_{2}\right]^{-}$Cluster Anion}

$\left[\mathrm{Cl} \cdot \mathrm{Na} \cdot \mathrm{ClO}_{2}\right]^{-}$cluster anions react with $\mathrm{SO}_{2}$ at room temperature giving rise to the products shown in Scheme 1, through a complex series of parallel and consecutive reactions. A kinetic plot showing the time progress of the reaction is displayed in Figure 3. The identity of the ionic products from reactions $1-5$ has been probed by collision-induced dissociation as discussed in the following. As reported in Table 1 , the reaction of $\left[\mathrm{Cl} \cdot \mathrm{Na} \cdot \mathrm{ClO}_{2}\right]^{-}$has a rate constant $\left(\mathrm{k}_{\mathrm{dec}}\right)$ of $2.88 \times 10^{-10}( \pm 30 \%) \mathrm{cm}^{3} \mathrm{~s}^{-1} \mathrm{~mol}^{-1}$ and an efficiency $\left(\mathrm{k} / \mathrm{k}_{\text {coll }}\right)$ of $24.2 \%$. 


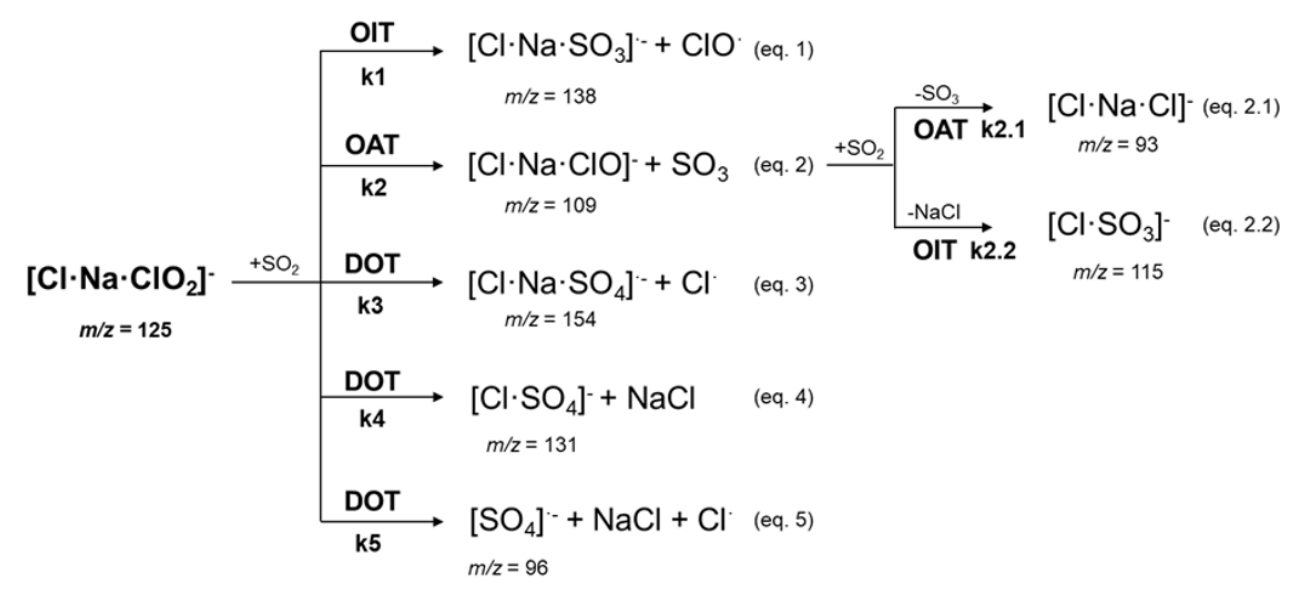

Scheme 1. Reactivity scheme $\left[\mathrm{Cl} \cdot \mathrm{Na} \cdot \mathrm{ClO}_{2}\right]^{-}$ions $(m / z=125)$ with $\mathrm{SO}_{2}$. Oxygen transfer channels (OIT, OAT, DOT) and bimolecular rate constants are indicated for each reaction.

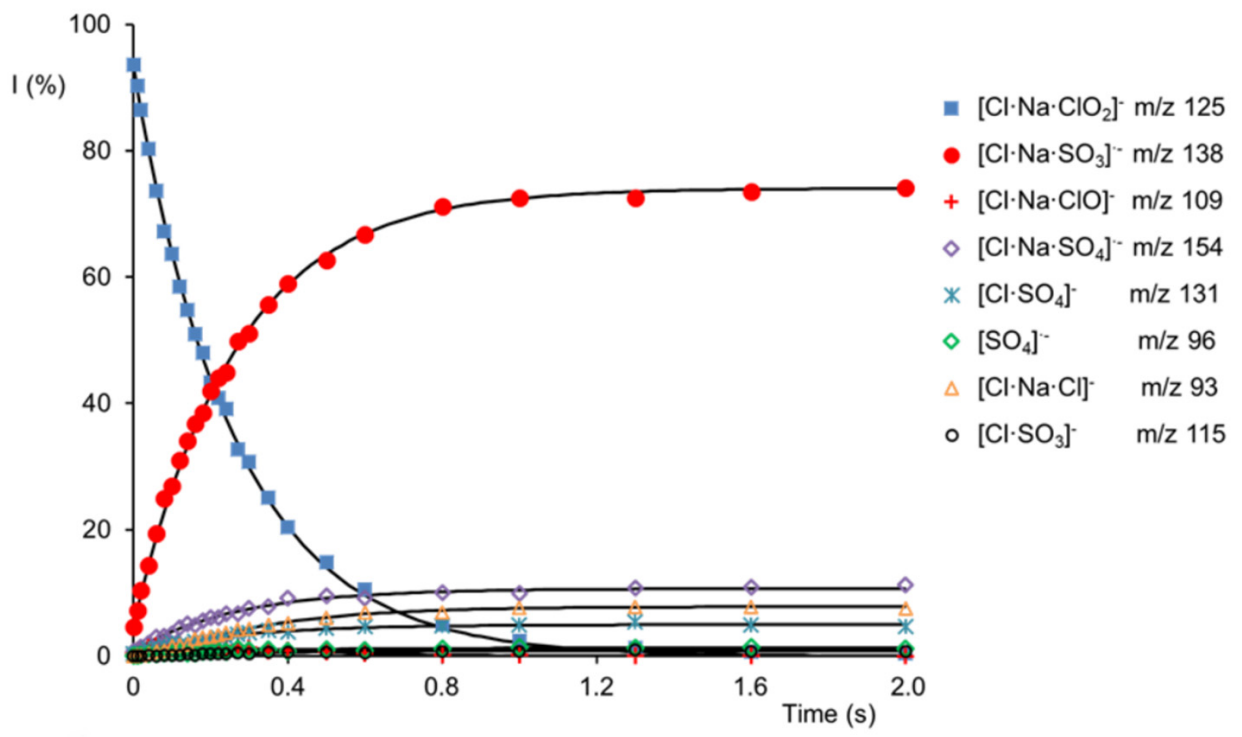

Figure 3. Kinetic plot and best fit lines of the reaction of isolated $\left[\mathrm{NaCl} \cdot \mathrm{ClO}_{2}\right]^{-}$ions $(\mathrm{m} / z=125)$ with $\mathrm{SO}_{2} . \mathrm{P} \mathrm{SO}_{2}=5.26 \times 10^{-7}$ Torr. $\square\left[\mathrm{Cl} \cdot \mathrm{Na} \cdot \mathrm{ClO}_{2}\right]^{-}(\mathrm{m} / \mathrm{z} 125)\left(\mathrm{R}^{2}=0.9991\right) ; \bullet\left[\mathrm{Cl} \cdot \mathrm{Na} \cdot \mathrm{SO}_{3}\right]^{\cdot-}(\mathrm{m} / z$ 138) $\left(\mathrm{R}^{2}=0.9986\right) ;+[\mathrm{Cl} \cdot \mathrm{Na} \cdot \mathrm{ClO}]^{-}\left(m / z\right.$ 109) $\left(\mathrm{R}^{2}=0.9770\right) ; \diamond\left[\mathrm{Cl} \cdot \mathrm{Na} \cdot \mathrm{SO}_{4}\right]^{\cdot-}\left(m / z\right.$ 154) $\left(\mathrm{R}^{2}=0.9915\right) ;$ $\times\left[\mathrm{Cl} \cdot \mathrm{SO}_{4}\right]^{-}(m / z 131)\left(\mathrm{R}^{2}=0.9868\right) ; \diamond\left[\mathrm{SO}_{4}\right]^{\cdot-}\left(m / z\right.$ 96) $\left(\mathrm{R}^{2}=0.9846\right) ; \triangle[\mathrm{Cl} \cdot \mathrm{Na} \cdot \mathrm{Cl}]^{-}(m / z 93)$ $\left(\mathrm{R}^{2}=0.9946\right) ; \bigcirc\left[\mathrm{Cl} \cdot \mathrm{SO}_{3}\right]^{-}(m / z 115)\left(\mathrm{R}^{2}=0.9946\right)$.

Although the larger size of $\left[\mathrm{Cl} \cdot \mathrm{Na} \cdot \mathrm{ClO}_{2}\right]^{-}$is predictably responsible for the decrease of the overall reaction rate compared to that of naked $\mathrm{ClO}_{2}^{-}\left(2.88 \mathrm{vs} .9 .10 \times 10^{-10} \mathrm{~cm}^{3} \mathrm{~s}^{-1} \mathrm{~mol}^{-1}\right)$, the intrinsic reactivity of the two ionic species is comparable, except for small differences in the branching ratios of the three oxygen transfer reactions. For the sake of clarity, the reactivity, OIT, OAT and DOT, is indicated in each reaction channel. 
Table 1. Rate constants $\left(\mathrm{cm}^{3} \mathrm{~s}^{-1} \mathrm{~mol}^{-1}\right)$, branching ratios $(\% \Sigma)$ and efficiencies $\left(\mathrm{k} / \mathrm{k}_{\mathrm{coll}}\right)$ for the reactions of $\left[\mathrm{L} \cdot \mathrm{M} \cdot \mathrm{ClO}_{2}\right]^{-}\left(\mathrm{L}=\mathrm{Cl}, \mathrm{F}, \mathrm{Br}, \mathrm{I}, \mathrm{ClO}_{2}, \mathrm{SO}_{3} ; \mathrm{M}=\mathrm{Na}, \mathrm{Li}\right)$ anions with $\mathrm{SO}_{2}$. The reaction of $\mathrm{ClO}_{2}{ }^{-}$with $\mathrm{SO}_{2}$ is also reported for comparative purposes. OIT: oxygen ion transfer; OAT: oxygen atom transfer; DOT: double oxygen transfer.

\begin{tabular}{|c|c|c|c|c|c|}
\hline Reaction & $k_{\text {dec }}\left(\times 10^{-10}\right)^{\S}$ & $\mathrm{k} / \mathrm{k}_{\text {coll }}(\%)$ & OIT & OAT & DOT \\
\hline $\mathrm{ClO}_{2}^{-}+\mathrm{SO}_{2}[47]$ & 9.10 & 63.8 & 86.5 & 4.2 & 9.3 \\
\hline$\left[\mathrm{Cl} \cdot \mathrm{Na} \cdot \mathrm{ClO}_{2}\right]^{-}+\mathrm{SO}_{2}$ & 2.88 & 24.2 & 74.2 & 8.8 & 17.0 \\
\hline$\left[\mathrm{F} \cdot \mathrm{Na} \cdot \mathrm{ClO}_{2}\right]^{-}+\mathrm{SO}_{2}$ & 3.75 & 30.8 & 89.2 & 3.7 & 7.1 \\
\hline$\left[\mathrm{Br} \cdot \mathrm{Na} \cdot \mathrm{ClO}_{2}\right]^{-}+\mathrm{SO}_{2}$ & 2.12 & 18.7 & 73.4 & 10.1 & 16.5 \\
\hline$\left[\mathrm{I} \cdot \mathrm{Na} \cdot \mathrm{ClO}_{2}\right]^{-}+\mathrm{SO}_{2}$ & 1.85 & 16.8 & 68.9 & 13.7 & 17.4 \\
\hline$\left[\mathrm{Cl} \cdot \mathrm{Li} \cdot \mathrm{ClO}_{2}\right]^{-}+\mathrm{SO}_{2}$ & 1.81 & 14.5 & 84.7 & 7.9 & 7.4 \\
\hline$\left[\mathrm{ClO}_{2} \cdot \mathrm{Na} \cdot \mathrm{ClO}_{2}\right]^{-}+\mathrm{SO}_{2}$ & 7.48 & 66.0 & 81.8 & 4.8 & 13.4 \\
\hline$\left[\mathrm{SO}_{3} \cdot \mathrm{Na} \cdot \mathrm{ClO}_{2}\right]^{-}+\mathrm{SO}_{2}$ & 3.74 & 33.0 & 70.4 & 6.9 & 22.7 \\
\hline$\left[\left(\mathrm{NaClO}_{2}\right)_{2} \cdot \mathrm{ClO}_{2}\right]^{-}+\mathrm{SO}_{2}$ & 7.39 & 68.1 & - & - & - \\
\hline
\end{tabular}
$\S \pm 30 \%$.

The main reaction of $\left[\mathrm{Cl} \cdot \mathrm{Na} \cdot \mathrm{ClO}_{2}\right]^{-}$leads to the formation of the ionic product $\left[\mathrm{Cl} \cdot \mathrm{Na} \cdot \mathrm{SO}_{3}\right]^{\cdot-}$ at $m / z 138$ and a $\mathrm{ClO}^{\cdot}$ radical species (Equation (1)). The reaction proceeds quickly with a rate constant $\mathrm{k}_{1}$ of $2.13 \times 10^{-10}( \pm 30 \%) \mathrm{cm}^{3} \mathrm{~s}^{-1} \mathrm{~mol}^{-1}$ (Table 2), and a branching ratio of $74.2 \%$ (Table 1 ). The collision-induced dissociation of the product ion at $m / z 138$ gives rise to the $\mathrm{SO}_{3}{ }^{-}$ion at $m / z=80$ (Figure S3) through the loss of a neutral $\mathrm{NaCl}$ consistent with a $\left[\mathrm{Cl} \cdot \mathrm{Na} \cdot \mathrm{SO}_{3}\right]^{\cdot-}$ connectivity, hinting at the occurrence of an intracluster oxidation of $\mathrm{SO}_{2}$ to $\mathrm{SO}_{3}{ }^{-}$through an oxygen ion transfer (OIT) process.

Table 2. Rate constants $\left(\mathrm{cm}^{3} \mathrm{~mol}^{-1} \mathrm{~s}^{-1}\right)$ for the reactions of the $\left[\mathrm{Cl} \cdot \mathrm{Na} \cdot \mathrm{ClO}_{2}\right]^{-}$anion with $\mathrm{SO}_{2}$. OIT: oxygen ion transfer; OAT: oxygen atom transfer; DOT: double oxygen transfer.

\begin{tabular}{|c|c|c|c|}
\hline Reactivity & \multicolumn{3}{|c|}{$\mathrm{k} \times 10^{-10} \mathrm{~cm}^{3} \mathrm{~mol}^{-1} \mathrm{~s}^{-1 \S}$} \\
\hline OIT & $\begin{array}{c}\mathrm{k}_{1} \\
2.13\end{array}$ & $\begin{array}{c}\mathrm{k}_{2.2} \\
0.743\end{array}$ & \\
\hline OAT & $\begin{array}{c}\mathrm{k}_{2} \\
0.251\end{array}$ & $\begin{array}{l}\mathrm{k}_{2.1} \\
7.53\end{array}$ & \\
\hline DOT & $\begin{array}{c}\mathrm{k}_{3} \\
0.306\end{array}$ & $\begin{array}{c}\mathrm{k}_{4} \\
0.147\end{array}$ & $\begin{array}{c}\mathrm{k}_{5} \\
0.034\end{array}$ \\
\hline
\end{tabular}

$\S \pm 30 \%$

Furthermore, $\left[\mathrm{Cl} \cdot \mathrm{Na} \cdot \mathrm{SO}_{3}\right]^{--}$was found to be unreactive towards $\mathrm{SO}_{2}$ thus confirming the presence of the two notoriously inert $\mathrm{Cl}^{-}$and $\mathrm{SO}_{3}{ }^{-}$moieties [47]. The $\mathrm{Cl}^{-}$anion only plays a spectator role, whereas the sodium cation is reasonably involved in the coordination of both $\mathrm{Cl}^{-}$and $\mathrm{SO}_{3} \cdot{ }^{-}$anions.

A minor channel gives rise to $[\mathrm{Cl} \cdot \mathrm{Na} \cdot \mathrm{ClO}]^{-}$at $m / z 109$ and $\mathrm{SO}_{3}$ (Equation (2)), with a rate constant $\mathrm{k}_{2}$ of $2.51 \times 10^{-11}( \pm 30 \%) \mathrm{cm}^{3} \mathrm{~s}^{-1} \mathrm{~mol}^{-1}$ (Table 2), and a branching ratio of $8.8 \%$ (Table 1). The product ion $[\mathrm{Cl} \cdot \mathrm{Na} \cdot \mathrm{ClO}]^{-}$at $m / z 109$ resembles an aggregate in which a $\mathrm{Cl}^{-}$spectator anion and a $\mathrm{ClO}^{-}$moiety are both coordinated to sodium cation, as evidenced by its CID mass spectrum. Through this path, $\mathrm{SO}_{2}$ is therefore oxidised to $\mathrm{SO}_{3}$ by an oxygen atom transfer $(\mathrm{OAT})$ reaction. Once formed, $[\mathrm{Cl} \cdot \mathrm{Na} \cdot \mathrm{ClO}]^{-}$displays the distinctive reactivity of the surrounding $\mathrm{ClO}^{-}$moiety towards $\mathrm{SO}_{2}$ [47] that consists in a further $\mathrm{SO}_{2}$ to $\mathrm{SO}_{3}$ conversion (Equation (2.1)), through a second OAT process, and in an intracluster reaction giving $\left[\mathrm{Cl} \cdot \mathrm{SO}_{3}\right]^{-}$at $m / z=115$ through an OIT process (Equation (2.2)). The rate constants of the two competitive processes are respectively $\mathrm{k}_{2.1}=7.53 \times 10^{-10}$ $( \pm 30 \%)$ and $\mathrm{k}_{2.2}=7.43 \times 10^{-11}( \pm 30 \%) \mathrm{cm}^{3} \mathrm{~s}^{-1} \mathrm{~mol}^{-1}$ (Table 2). Not surprisingly, the OAT undergone by $\left[\mathrm{Cl} \cdot \mathrm{Na} \cdot \mathrm{ClO}_{2}\right]^{-}$(Equation (2)) is slower with respect to the same process undergone by $[\mathrm{Cl} \cdot \mathrm{Na} \cdot \mathrm{ClO}]^{-}$(Equation (2.1)), reflecting the different reactivity of the free 
$\mathrm{ClO}_{2}{ }^{-}$and $\mathrm{ClO}^{-}$species [47]. The first preferably oxidises $\mathrm{SO}_{2}$ through an OIT process, whereas the OAT is faster in the case of $\mathrm{ClO}^{-}$.

Finally, the $\left[\mathrm{Cl} \cdot \mathrm{Na} \cdot \mathrm{ClO}_{2}\right]^{-}$parent ion is involved in different reactions collectively responsible for a double oxygen transfer (DOT) to $\mathrm{SO}_{2}$ with the formation of product ions containing a sulphate anion, $\mathrm{SO}_{4}{ }^{\cdot-}$ (Equations (3)-(5)). The sulphate moiety can be either found as a clustered ion, as in Equations (3) and (4), or it can be a free anion as in Equation (5). In Reactions (3) and (4), upon the oxidation of $\mathrm{SO}_{2}$ to $\mathrm{SO}_{4}{ }^{\cdot-}$, a $\mathrm{NaCl}$ or Cl neutral moieties are respectively released. In any case, it is formed through an overall $\mathrm{O}_{2}{ }^{-}$transfer and the DOT processes account for a branching ratio of $17.0 \%$ (Table 1 ).

The ionic product at $m / z 154$ (Equation (3)) is consistent with a $\left[\mathrm{Cl} \cdot \mathrm{Na} \cdot \mathrm{SO}_{4}\right]^{-}$structure according to its fragmentation into $\mathrm{SO}_{4}{ }^{\cdot-}$ ion at $m / z=96$ (Figure S4) and loss of the neutral $\mathrm{NaCl}$. The reaction occurs with a rate constant $\mathrm{k}_{3}$ of $3.06 \times 10^{-11}( \pm 30 \%) \mathrm{cm}^{3} \mathrm{~s}^{-1} \mathrm{~mol}^{-1}$ and represents the main DOT path. Alternatively, the $\mathrm{SO}_{4}{ }^{\cdot-}$ moiety can remain attached to the $\mathrm{Cl}^{-}$radical, and releasing a $\mathrm{NaCl}$ moiety leads to the product ion $\left[\mathrm{Cl} \cdot \mathrm{SO}_{4}\right]^{-}$at $\mathrm{m} / z 131$ with a $\mathrm{k}_{4}$ of $1.47 \times 10^{-11}( \pm 30 \%) \mathrm{cm}^{3} \mathrm{~s}^{-1} \mathrm{~mol}^{-1}$ (Equation (4)). According to the electron affinity values for $\mathrm{SO}_{4}(\mathrm{EA}=5.10 \mathrm{eV})$ and $\mathrm{Cl}(\mathrm{EA}=3.61 \mathrm{eV})[64]$, the negative charge of the $\left[\mathrm{Cl} \cdot \mathrm{SO}_{4}\right]^{-}$product ion is mostly located on the $\mathrm{SO}_{4}$ moiety, as confirmed by the dissociation of this cluster into $\mathrm{SO}_{4}{ }^{--}$ion at $m / z=96$ (Figure S5).

Finally, $\mathrm{SO}_{4}{ }^{-}$is also generated as a free ion through reaction 5 with a $\mathrm{k}_{5}$ of $3.4 \times 10^{-12}$ $( \pm 30 \%) \mathrm{cm}^{3} \mathrm{~s}^{-1} \mathrm{~mol}^{-1}$. Not surprisingly, the free $\mathrm{SO}_{4}{ }^{--}$ion is the least abundant product formed through the DOT paths. In the clustered species, $\left[\mathrm{Cl} \cdot \mathrm{SO}_{4}\right]^{-}$and $\left[\mathrm{Cl} \cdot \mathrm{Na} \cdot \mathrm{SO}_{4}\right]^{\cdot-}$, the negative charge can be more favourably dispersed in larger species.

The comparison with the reactivity of the free $\mathrm{ClO}_{2}{ }^{-}$anion shows that also with the $\left[\mathrm{Cl} \cdot \mathrm{Na} \cdot \mathrm{ClO}_{2}\right]^{-}$clustered anions the OIT remains the main reaction channel. When $\mathrm{ClO}_{2}{ }^{-}$was reacted with $\mathrm{SO}_{2}$, the small differences in the electron affinities between $\mathrm{ClO}^{-}$ (EA of $2.27 \mathrm{eV}$ ) and $\mathrm{SO}_{3}$ (EA of $2.06 \mathrm{eV}$ ) [64] only resulted in close energies (-24.6 and $\left.-25.6 \mathrm{kcal} \mathrm{mol}^{-1}\right)$ calculated for the two alternative exit channels, namely $\mathrm{SO}_{3} \cdot{ }^{\cdot-}(+\mathrm{ClO} \cdot)$ and $\mathrm{SO}_{3}\left(+\mathrm{ClO}^{-}\right)$[47]; therefore, the prevalence of the OIT process was attributed to kinetic factors. Contrarywise, thermochemical factors favoured the OAT reaction over the OIT process in the reactivity of the free $\mathrm{ClO}^{-}$anion with $\mathrm{SO}_{2}$ due to the significantly higher electron affinity of $\mathrm{Cl}(\mathrm{EA}=3.61 \mathrm{eV})$ with respect to that of $\mathrm{SO}_{3}(\mathrm{EA}=2.06 \mathrm{eV})$. Accordingly, in the reactivity of $[\mathrm{Cl} \cdot \mathrm{Na} \cdot \mathrm{ClO}]^{-}$ion, OAT (Equation (2.1)) prevails over the OIT process (Equation (2.2)) by a ratio of ca. 10/1. The in-depth theoretical analyses performed on the free $\mathrm{ClO}_{2}{ }^{-}$species [47] can also give some insights into the reactivity observed with the clustered chlorite anions. The potential energy surface (PES) of $\left[\mathrm{OClO}-\mathrm{SO}_{2}\right]^{-}$system, was characterised by an early transition state that accounts for the almost barrierless formation of $\mathrm{SO}_{3}{ }^{-}$. In the TS, the negative charge is exclusively located on the preformed $\mathrm{SO}_{3}$ group $\left(1.02 \mathrm{e}^{-}\right)$, that is prone to rapid dissociation into the sulphite radical anion, and that strongly competes with the OAT and DOT processes. The formation of $\mathrm{SO}_{3}$ and $\mathrm{SO}_{4}{ }^{--}$ occurs through common intermediates, found on the double well PES, which dissociate reflecting the endothermicity of the two processes. This theoretical analysis is well suited to also explain the reactivity observed for the ligated $\left[\mathrm{Cl} \cdot \mathrm{Na} \cdot \mathrm{ClO}_{2}\right]^{-}$cluster ions with $\mathrm{SO}_{2}$, and that of the other ligated species described in the following sections. The $\mathrm{NaCl}$ ligand does not affect the outcome of the oxidation reactions. Rather, it seems to have the effect of spreading the charge on the cluster, eventually lowering the reaction rate.

Overall, an increase of DOT and OAT processes at the expense of OIT channel is evidenced for the $\left[\mathrm{Cl} \cdot \mathrm{Na} \cdot \mathrm{ClO}_{2}\right]^{-}$cluster ion with respect to the non-clustered $\mathrm{ClO}_{2}{ }^{-}$anion.

\section{Effect of the Ligand}

To deeply investigate the role of the $\mathrm{NaCl}$ ligand in the reactivity of $\left[\mathrm{Cl} \cdot \mathrm{Na} \cdot \mathrm{ClO}_{2}\right]^{-}$ ion towards $\mathrm{SO}_{2}, \mathrm{Cl}^{-}$was first replaced by $\mathrm{X}$ anion $(\mathrm{X}=\mathrm{F}, \mathrm{Br}$, I) to form the corresponding $\left[\mathrm{X} \cdot \mathrm{Na} \cdot \mathrm{ClO}_{2}\right]^{-}$reactive species and subsequently $\mathrm{Li}^{+}$was inserted in place of $\mathrm{Na}^{+}$to evaluate the role of the cation. Only non-redox-active ligands were used in order to make a 
comparison with the effect of salinity in solution, where it is known that the increase in ionic strength determines an increase in the absorption efficiency of $\mathrm{SO}_{2}$, [18].

As reported in Table 1, the overall rate constant $\left(\mathrm{k}_{\mathrm{dec}}\right)$ increases with the charge density of $X$ anion, reaching the highest value of $3.75 \times 10^{-10}( \pm 30 \%) \mathrm{cm}^{3} \mathrm{~s}^{-1} \mathrm{~mol}^{-1}$ with the smallest $\mathrm{F}$ anion (ion radius $=136 \mathrm{pm}$ ) and the lowest value of $1.85 \times 10^{-10}$ $( \pm 30 \%) \mathrm{cm}^{3} \mathrm{~s}^{-1} \mathrm{~mol}^{-1}$ with the largest I anion (ion radius $\left.=216 \mathrm{pm}\right)$ (Table 1) [65].

Regarding the branching ratios of the three reaction channels, $\left[\mathrm{I} \cdot \mathrm{Na} \cdot \mathrm{ClO}_{2}\right]^{-}$and $\left[\mathrm{Br} \cdot \mathrm{Na} \cdot \mathrm{ClO}_{2}\right]^{-}$show a reactivity distribution comparable to that of the $\left[\mathrm{Cl} \cdot \mathrm{Na} \cdot \mathrm{ClO}_{2}\right]^{-}$ ion. On the contrary, an increase of the OIT process at the expense of the OAT and DOT channels was reported for $\left[\mathrm{F} \cdot \mathrm{Na} \cdot \mathrm{ClO}_{2}\right]^{-}$cluster species. As a consequence of the high charge density on the fluoride ion, the $\left[\mathrm{F} \cdot \mathrm{Na} \cdot \mathrm{SO}_{3}\right]^{--}$ionic product arising from the OIT process adds an $\mathrm{SO}_{2}$ molecule giving rise to a labile adduct of the type $\left[\mathrm{F} \cdot \mathrm{Na} \cdot \mathrm{SO}_{3} \cdot \mathrm{SO}_{2}\right]^{--}$ never observed with the other reactant ions. The OAT process increases down the halogen series, whereas the opposite occurs with the OIT process.

Passing to the cation effect, an opposite trend was observed, as the reaction rate decreases by increasing the positive charge density on the metal. The overall rate constant for the $\left[\mathrm{Cl} \cdot \mathrm{Li} \cdot \mathrm{ClO}_{2}\right]^{-}+\mathrm{SO}_{2}$ reaction is indeed almost three times lower than the corresponding value for the $\left[\mathrm{Cl} \cdot \mathrm{Na} \cdot \mathrm{ClO}_{2}\right]^{-}+\mathrm{SO}_{2}$ system, highlighting the central role of an external electric field in modelling the reaction kinetics. [54-56] Minor effect of the charge density is instead reported for the general reactivity scheme of $\left[\mathrm{Cl} \cdot \mathrm{Li} \cdot \mathrm{ClO}_{2}\right]^{-}$anion.

The main role played by the different ligands described above might be due to the spreading the negative charge of $\mathrm{ClO}_{2}{ }^{-}$within the cluster, the effect of which is reflected in the oxidative capacity of $\mathrm{ClO}_{2}{ }^{-}$ion: the higher the charge density of the ligand, the faster the reaction. Passing from $\mathrm{F}^{-}$to $\mathrm{I}^{-}$, the former forms a tighter ion pair with $\mathrm{Na}^{+}$, making the chlorite anion more available to oxidise sulphur dioxide. A second effect concerns the steric hindrance to the approach of $\mathrm{SO}_{2}$ due to the neutral ligand, whereby ligands of larger dimensions lead to a decrease in the overall reaction rate. An opposite effect is observed with the lithium cation, whose small size increases the interactions with both $\mathrm{Cl}^{-}$and $\mathrm{ClO}_{2}{ }^{-}$, reducing the oxygen transfer rate of the latter. The effect of the non-redox ligands here tested is different to that played in solution, where an increase in ionic strength (i.e., the salinity) has the effect of increasing the $\mathrm{SO}_{2}$ absorption efficiency by the solutions and therefore the overall efficiency of wet scrubbing processes [18].

\subsection{Reactivity of $\left[\mathrm{ClO}_{2} \cdot \mathrm{Na} \cdot \mathrm{ClO}_{2}\right]^{-}$Cluster Anion}

Passing to $\left[\mathrm{ClO}_{2} \cdot \mathrm{Na} \cdot \mathrm{ClO}_{2}\right]^{-}$cluster ion, the reactive channels reported in Scheme 2 have been observed from the reaction with $\mathrm{SO}_{2}$. The identity of the ionic products from Reactions (6)-(11) have been probed by collision-induced dissociation experiments as discussed below.

The reaction of $\left[\mathrm{ClO}_{2} \cdot \mathrm{Na} \cdot \mathrm{ClO}_{2}\right]^{-}$with $\mathrm{SO}_{2}$ at $298 \mathrm{~K}$ is fast and efficient showing an overall rate constant $\left(\mathrm{k}_{\mathrm{dec}}\right)$ of $7.48 \times 10^{-10}( \pm 30 \%) \mathrm{cm}^{3} \mathrm{~s}^{-1} \mathrm{~mol}^{-1}$ at $298 \mathrm{~K}$. This value is only 0.82 times lower than the corresponding one for the bare $\mathrm{ClO}_{2}{ }^{-}$species, whereas the efficiencies $\left(\mathrm{k} / \mathrm{k}_{\text {coll }}\right)$ of the two processes are similar $(66.0 \%$ vs. $63.8 \%$, Table 1$)$. The intrinsic reactivity of the $\left[\mathrm{ClO}_{2} \cdot \mathrm{Na} \cdot \mathrm{ClO}_{2}\right]^{-}$anion towards $\mathrm{SO}_{2}$ is comparable to that of the $\left[\mathrm{Cl} \cdot \mathrm{Na} \cdot \mathrm{ClO}_{2}\right]^{-}$species, as demonstrated by rather close branching ratios for the three reaction pathways (Table 1). Nonetheless, the concomitant presence of two reactive $\mathrm{ClO}_{2}{ }^{-}$ moieties in the $\left[\mathrm{ClO}_{2} \cdot \mathrm{Na} \cdot \mathrm{ClO}_{2}\right]^{-}$ion gives rise to an intricate reaction picture as shown in the above Scheme 2 and in the kinetic plot of Figure 4. 


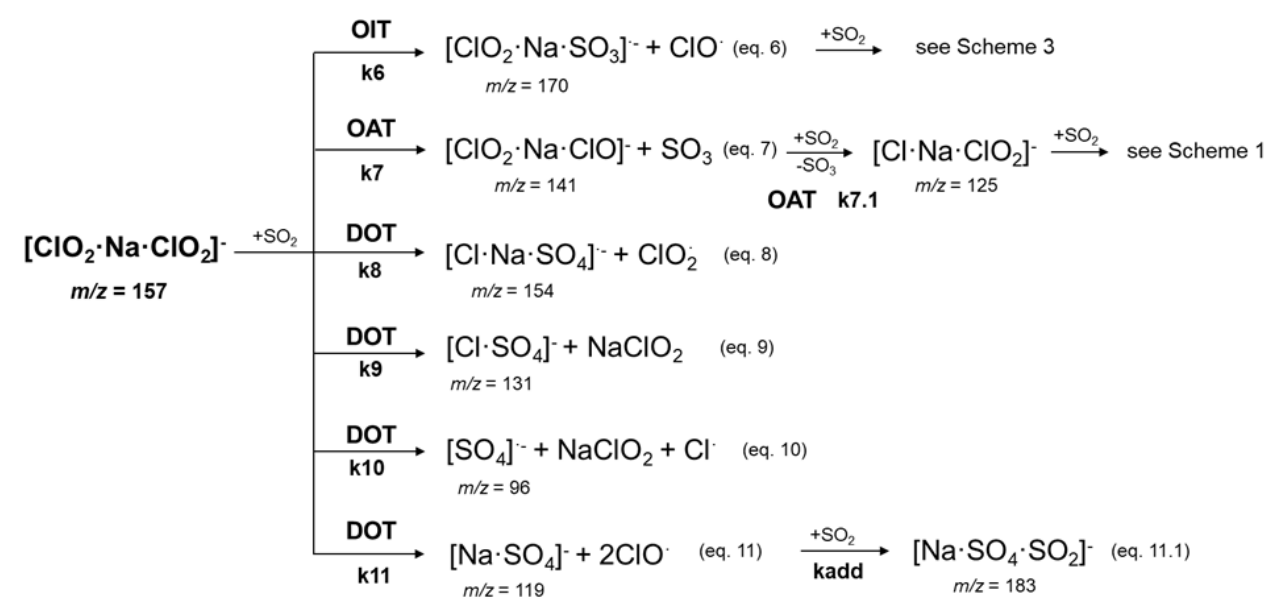

Scheme 2. Reactivity scheme $\left[\mathrm{ClO}_{2} \cdot \mathrm{Na} \cdot \mathrm{ClO}_{2}\right]^{-}$ions $(m / z=157)$ with $\mathrm{SO}_{2}$. Oxygen transfer channels (OIT, OAT, DOT) and bimolecular rate constants are indicated for each reaction.

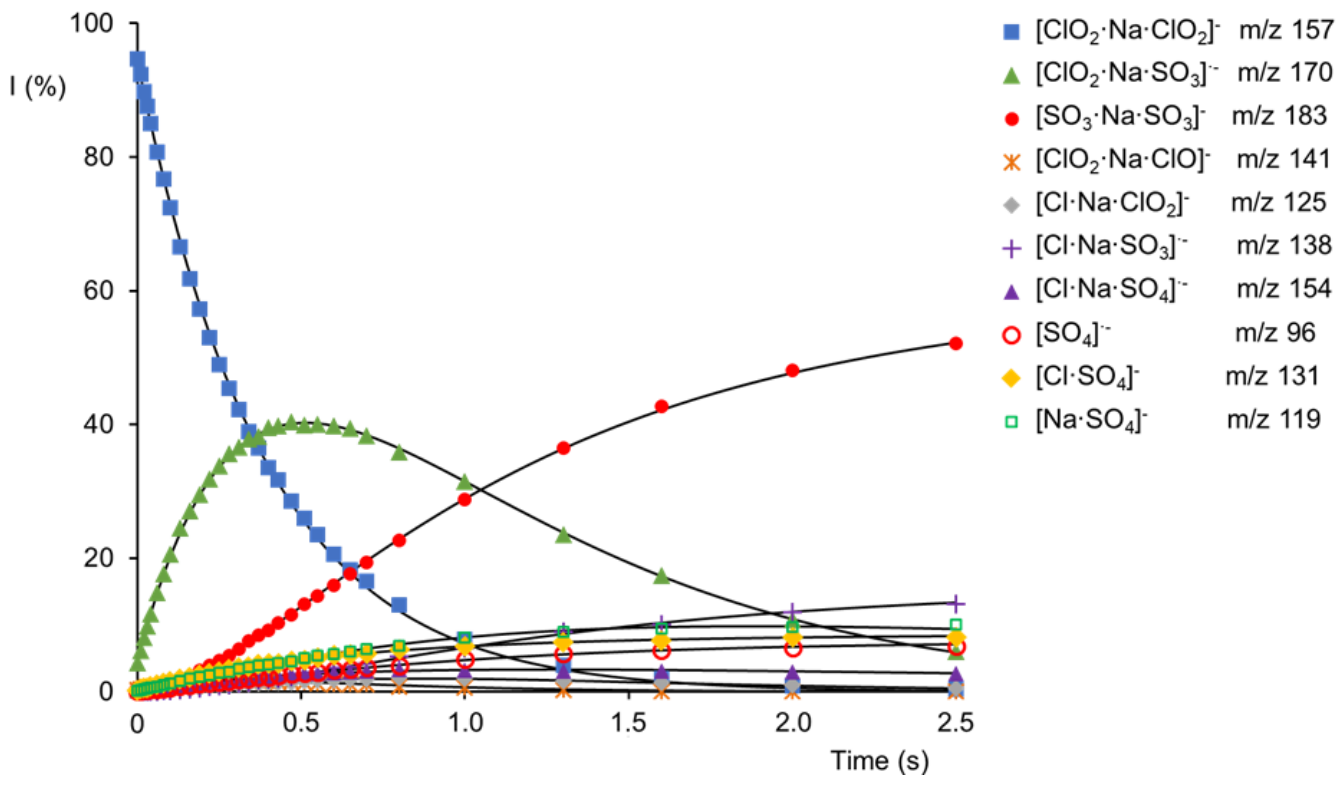

Figure 4. Kinetic plot and best fit lines of the reaction of isolated $\left[\mathrm{NaClO}_{2} \cdot \mathrm{ClO}_{2}\right]^{-}$ions $(\mathrm{m} / z=157)$ with $\mathrm{SO}_{2} . \mathrm{P} \mathrm{SO}_{2}=3.30 \times 10^{-7}$ Torr. $\square\left[\mathrm{ClO}_{2} \cdot \mathrm{Na} \cdot \mathrm{ClO}_{2}\right]^{-}\left(\mathrm{m} / z\right.$ 157) $\left(\mathrm{R}^{2}=0.9991\right) ; \mathbf{\Delta}\left[\mathrm{ClO}_{2} \cdot \mathrm{Na} \cdot \mathrm{SO}_{3}\right]^{\cdot-}$ $\left(m / z\right.$ 170) $\left(\mathrm{R}^{2}=0.9986\right) ; \bullet\left[\mathrm{SO}_{3} \cdot \mathrm{Na} \cdot \mathrm{SO}_{3}\right]^{-}(m / z 183)\left(\mathrm{R}^{2}=0.9998\right) ; \times\left[\mathrm{ClO}_{2} \cdot \mathrm{Na} \cdot \mathrm{ClO}\right]^{-}(m / z 141)$ $\left(\mathrm{R}^{2}=0.9888\right) ; \quad\left[\mathrm{Cl} \cdot \mathrm{Na} \cdot \mathrm{ClO}_{2}\right]^{-}\left(m / z\right.$ 125) $\left(\mathrm{R}^{2}=0.9965\right) ;+\left[\mathrm{Cl} \cdot \mathrm{Na} \cdot \mathrm{SO}_{3}\right]^{-}(\mathrm{m} / z \mathrm{138})\left(\mathrm{R}^{2}=0.9967\right) ;$ $\Delta\left[\mathrm{Cl} \cdot \mathrm{Na} \cdot \mathrm{SO}_{4}\right]^{--}\left(m / z\right.$ 154) $\left(\mathrm{R}^{2}=0.9912\right) ; \bigcirc\left[\mathrm{SO}_{4}\right]^{--}\left(m / z\right.$ 96) $\left(\mathrm{R}^{2}=0.9946\right) ; \diamond\left[\mathrm{Cl} \cdot \mathrm{SO}_{4}\right]^{-}(m / z 131)$ $\left(\mathrm{R}^{2}=0.9992\right) ; \square\left[\mathrm{Na} \cdot \mathrm{SO}_{4}\right]^{-}(m / z 119)\left(\mathrm{R}^{2}=0.9971\right)$.

The main reaction of $\left[\mathrm{ClO}_{2} \cdot \mathrm{Na} \cdot \mathrm{ClO}_{2}\right]^{-}$ion at $\mathrm{m} / z 157$ leads to the ionic product at $m / z 170$, attributed to $\left[\mathrm{ClO}_{2} \cdot \mathrm{Na} \cdot \mathrm{SO}_{3}\right]^{\cdot-}$, and a $\mathrm{ClO} \cdot$ radical species (Equation (6)). The CID mass spectrum of the ionic product at $m / z 170$ shows a major dissociation into $\mathrm{SO}_{3}{ }^{\cdot-}$, which accounts for a $\left[\mathrm{ClO}_{2} \cdot \mathrm{Na} \cdot \mathrm{SO}_{3}\right]^{\cdot-}$ structure (Figure S7). As in the case of Cl-clustered species $\left[\mathrm{Cl} \cdot \mathrm{Na} \cdot \mathrm{ClO}_{2}\right]^{-}$, the main reaction of $\left[\mathrm{ClO}_{2} \cdot \mathrm{Na} \cdot \mathrm{ClO}_{2}\right]^{-}$consists of an oxygen ion transfer, resulting in a fast intracluster oxidation of $\mathrm{SO}_{2}$. The rate constant $\mathrm{k}_{6}$ is $6.26 \times 10^{-10}$ $( \pm 30 \%) \mathrm{cm}^{3} \mathrm{~s}^{-1} \mathrm{~mol}^{-1}$ (Table 3 ), and a branching ratio of $81.8 \%$ (Table 1 ). The intracluster formation of $\mathrm{SO}_{3}{ }^{-}$- gives rise to a negatively charged product in which one of the two $\mathrm{ClO}_{2}{ }^{-}$moieties only played a spectator role, whereas the sodium cation is reasonably involved in the coordination of the $\mathrm{ClO}_{2}{ }^{-}$and $\mathrm{SO}_{3}{ }^{-}-$anions. However, the presence of a residual $\mathrm{ClO}_{2}{ }^{-}$moiety in the product ion $\left[\mathrm{ClO}_{2} \cdot \mathrm{Na} \cdot \mathrm{SO}_{3}\right]^{\cdot-}$ is responsible for the consecutive reactivity of this species, which is deeply discussed in the next paragraph (vide 
infra). The complete reactive scheme of $\left[\mathrm{ClO}_{2} \cdot \mathrm{Na} \cdot \mathrm{ClO}_{2}\right]^{-}$, integrated with the reactivity of $\left[\mathrm{ClO}_{2} \cdot \mathrm{Na} \cdot \mathrm{SO}_{3}\right]^{\cdot-}$, is reported in the Supplementary Materials (Scheme S1), showing the complex and intricate reactivity of an only apparently simple species.

Table 3. Rate constants $\left(\mathrm{cm}^{3} \mathrm{~mol}^{-1} \mathrm{~s}^{-1}\right)$ for the reaction: $\left[\mathrm{ClO}_{2} \cdot \mathrm{Na} \cdot \mathrm{ClO}_{2}\right]^{-}+\mathrm{SO}_{2}$. Only the most relevant rate constants are reported. OIT: oxygen ion transfer; OAT: oxygen atom transfer; DOT: double oxygen transfer; add: addition reaction.

\begin{tabular}{|c|c|c|c|c|}
\hline \multirow{2}{*}{$\frac{\text { Reactivity }}{\text { OIT }}$} & \multicolumn{4}{|c|}{$\mathrm{k} \times 10^{-10} \mathrm{~cm}^{3} \mathrm{~mol}^{-1} \mathrm{~s}^{-1 \S}$} \\
\hline & $\begin{array}{c}\mathrm{k}_{6} \\
6.26\end{array}$ & & & \\
\hline OAT & $\begin{array}{c}\mathrm{k}_{7} \\
0.364\end{array}$ & $\begin{array}{l}\mathrm{k}_{7.1} \\
9.57\end{array}$ & & \\
\hline DOT & $\begin{array}{c}\mathrm{k}_{8} \\
0.251\end{array}$ & $\begin{array}{c}\mathrm{k}_{9} \\
0.417\end{array}$ & $\begin{array}{c}\mathrm{k}_{10} \\
0.134\end{array}$ & $\begin{array}{c}\mathrm{k}_{11} \\
0.222\end{array}$ \\
\hline $\mathrm{SO}_{2}$ add & $\begin{array}{c}\mathrm{k}_{\mathrm{SO} 2} \\
0.574\end{array}$ & & & \\
\hline
\end{tabular}

$\S \pm 30 \%$.

A second path, indeed a minor one, leads to an ionic product at $m / z 141$ and $\mathrm{SO}_{3}$ (Equation (7)), formed through an OAT from one of the two $\mathrm{ClO}_{2}{ }^{-}$unit to $\mathrm{SO}_{2}$. The branching ratio is only $4.8 \%$ (Table 1 ) and a rate constant $\mathrm{k}_{7}$ of $3.64 \times 10^{-11}( \pm 30 \%) \mathrm{cm}^{3} \mathrm{~s}^{-1} \mathrm{~mol}^{-1}$ (Table 3). The ionic product at $m / z 141$, resembles an aggregate in which a $\mathrm{ClO}_{2}{ }^{-}$anion and a $\mathrm{ClO}^{-}$reactive moiety are both coordinated to sodium cation, although its fragmentation into the $\mathrm{ClO}_{3}{ }^{-}$species at $\mathrm{m} / z 83$ seems to account for a $\left[\mathrm{Cl} \cdot \mathrm{Na} \cdot \mathrm{ClO}_{3}\right]^{-}$structure (Figure S8). Nonetheless, the $\left[\mathrm{Cl} \cdot \mathrm{Na} \cdot \mathrm{ClO}_{3}\right]^{-}$ion obtained by spraying a $\mathrm{NaCl} / \mathrm{NaClO}_{3}(1: 1)$ millimolar solution resulted to be not reactive towards $\mathrm{SO}_{2}$ (Figure $\mathrm{S} 9$ ).

Therefore, it seems more likely to attribute the $\left[\mathrm{ClO} \cdot \mathrm{Na} \cdot \mathrm{ClO}_{2}\right]^{-}$connectivity to the ion at $m / z 141$ that rearranges to $\left[\mathrm{Cl} \cdot \mathrm{Na} \cdot \mathrm{ClO}_{3}\right]^{-}$upon $\mathrm{CID}$, thus demonstrating the interaction of sodium cation with the $\mathrm{ClO}_{2}{ }^{-}$and $\mathrm{ClO}^{-}$anions, rather than $\mathrm{Cl}^{-}$and $\mathrm{ClO}_{3}{ }^{-}$species. The presence of two potential reactive units, $\mathrm{ClO}$ and $\mathrm{ClO}_{2}$, make the $\left[\mathrm{ClO} \cdot \mathrm{Na} \cdot \mathrm{ClO}_{2}\right]^{-}$ cluster ion quite reactive. The consecutive OAT process observed (Equation (7.1)) has a rate constant $\mathrm{k}_{7.1}$ of $9.57 \times 10^{-10}( \pm 30 \%) \mathrm{cm}^{3} \mathrm{~s}^{-1} \mathrm{~mol}^{-1}$ (Table 3 ), which is much higher than $\mathrm{k}_{7}$ relative to the similar OAT process in Equation (7). Again, as for reactions 2 and 2.1 , the reason lies in the different reactivity of the free chlorite and hypochlorite anions, the first undergoing faster OIT and the second faster OAT processes. The product ion at $m / z 125$ corresponds to the $\left[\mathrm{Cl} \cdot \mathrm{Na} \cdot \mathrm{ClO}_{2}\right]^{-}$species, as demonstrated by its characteristic fragmentation pattern and the distinctive reactivity discussed in the previous paragraph (Figures S10 and S11).

Four different DOT channels were reported for the $\left[\mathrm{ClO}_{2} \cdot \mathrm{Na} \cdot \mathrm{ClO}_{2}\right]^{-}$parent ion. The first three pathways (Equations (8)-(10)) resemble those already described for the $\left[\mathrm{Cl} \cdot \mathrm{Na} \cdot \mathrm{ClO}_{2}\right]^{-}$ion (Equations (3)-(5)), as the same product ions at $m / z 154,131$, and 96 are respectively detected. The intracluster DOT processes reported in Equations (3) and (8) occurs with similar rate constants $\mathrm{k}_{3}$ and $\mathrm{k}_{8}$, regardless the ligand $[\mathrm{NaCl}]$ or $\left[\mathrm{NaClO}_{2}\right]$ attached to the $\mathrm{ClO}_{2}{ }^{-}$moiety $\left(\mathrm{k}_{3}=3.06 \mathrm{vs}\right.$. $\left.\mathrm{k}_{8}=2.51 \times 10^{-11} \mathrm{~cm}^{3} \mathrm{~s}^{-1} \mathrm{~mol}^{-1}\right)$. A significantly faster formation of the $\left[\mathrm{Cl} \cdot \mathrm{SO}_{4}\right]^{-}$ion at $m / z 131$ was reported for the $\left[\mathrm{ClO}_{2} \cdot \mathrm{Na} \cdot \mathrm{ClO}_{2}\right]^{-}$parent species with respect to $\left[\mathrm{Cl} \cdot \mathrm{Na} \cdot \mathrm{ClO}_{2}\right]^{-}\left(\mathrm{k}_{9}=4.17 \mathrm{vs}\right.$. $\left.\mathrm{k}_{4}=1.47 \times 10^{-11} \mathrm{~cm}^{3} \mathrm{~s}^{-1} \mathrm{~mol}^{-1}\right)$. Again, the formation of the free $\left[\mathrm{SO}_{4}\right]^{--}$product ion represents the lowest DOT process $\left(\mathrm{k}_{10}=1.34 \times 10^{-11} \mathrm{~cm}^{3} \mathrm{~s}^{-1} \mathrm{~mol}^{-1}\right)$. In addition, a fourth DOT channel was observed only for the $\left[\mathrm{ClO}_{2} \cdot \mathrm{Na} \cdot \mathrm{ClO}_{2}\right]^{-}$parent ion which is worthy of note. In this case, the oxidation of $\mathrm{SO}_{2}$ leads to the product at $m / z 119$ with a rate constant $\mathrm{k}_{11}$ of $2.22 \times 10^{-11} \mathrm{~cm}^{3} \mathrm{~s}^{-1} \mathrm{~mol}^{-1}$ (Equation (11)) which subsequently adds a further $\mathrm{SO}_{2}$ molecule with a $\mathrm{k}_{\text {add }}$ of $5.74 \times 10^{-11} \mathrm{~cm}^{3} \mathrm{~s}^{-1} \mathrm{~mol}^{-1}$ (Equation (11.1), Table 3). Although the structure of the ionic species at $m / z 119$ could not be directly probed owing to its unproductive CID, a possible $\left[\mathrm{Na} \cdot \mathrm{SO}_{4}\right]^{-}$formula can be reasonably supposed. The corresponding ion at $m / z 119$ was 
also obtained by electrospraying a solution of $\mathrm{Na}_{2} \mathrm{SO}_{4}$ which, once isolated and reacted with $\mathrm{SO}_{2}$, gave a ligated $\left[\mathrm{Na} \cdot \mathrm{SO}_{4} \cdot \mathrm{SO}_{2}\right]^{-}$addition product with a rate constant consistent with $\mathrm{k}_{\mathrm{add}}$, of Equation (11.1), thus confirming the identity of the parent species at $\mathrm{m} / z 119$ (Figure S12). The $\left[\mathrm{Na} \cdot \mathrm{SO}_{4}\right]^{-}$formula accounts for the oxidation of the sulphur atom of sulphur dioxide and the eventual reduction of the chlorine atoms of the $\left[\mathrm{ClO}_{2} \cdot \mathrm{Na} \cdot \mathrm{ClO}_{2}\right]^{-}$ion. Both the $\mathrm{ClO}_{2}{ }^{-}$units may be involved in the reaction, in which each $\mathrm{ClO}_{2}{ }^{-}$anion transfers an $\mathrm{O}^{-}$moiety to $\mathrm{SO}_{2}$ giving rise to an $\mathrm{SO}_{4}{ }^{2-}$ species and the release of two $\mathrm{ClO}^{-}$radicals. This hypothesis was confirmed by replacing one of the two $\mathrm{ClO}_{2}{ }^{-}$anions with the similarly oxygenated, but intrinsically unreactive $\mathrm{ClO}_{3}{ }^{-}$anion to obtain the $\left[\mathrm{ClO}_{3} \cdot \mathrm{Na} \cdot \mathrm{ClO}_{2}\right]^{-}$ parent ion. When exposed to $\mathrm{SO}_{2}$, this species shows an intrinsic reactivity comparable to that of the $\left[\mathrm{ClO}_{2} \cdot \mathrm{Na} \cdot \mathrm{ClO}_{2}\right]^{-}$ion with the only exception of the product at $m / z 119$ that was not observed, thus highlighting the involvement of both $\mathrm{ClO}_{2}{ }^{-}$anions in the double $\mathrm{O}^{\cdot-}$ transfer.

\subsection{Reactivity of $\left[\mathrm{SO}_{3} \cdot \mathrm{Na} \cdot \mathrm{ClO}_{2}\right]^{\cdot-}$ Cluster Anion}

To better investigate the consecutive reactivity of the product ion at $m / z 170$, arising from the $\left[\mathrm{ClO}_{2} \cdot \mathrm{Na} \cdot \mathrm{ClO}_{2}\right]^{-}$parent species through Equation (6), the putative $\left[\mathrm{ClO}_{2} \cdot \mathrm{Na} \cdot \mathrm{SO}_{3}\right]^{-}$ ion was isolated from the sequence 157 to 170 (MS ${ }^{2}$-isolated) and separately reacted with $\mathrm{SO}_{2}$. The reactivity observed is illustrated in Scheme 3 .

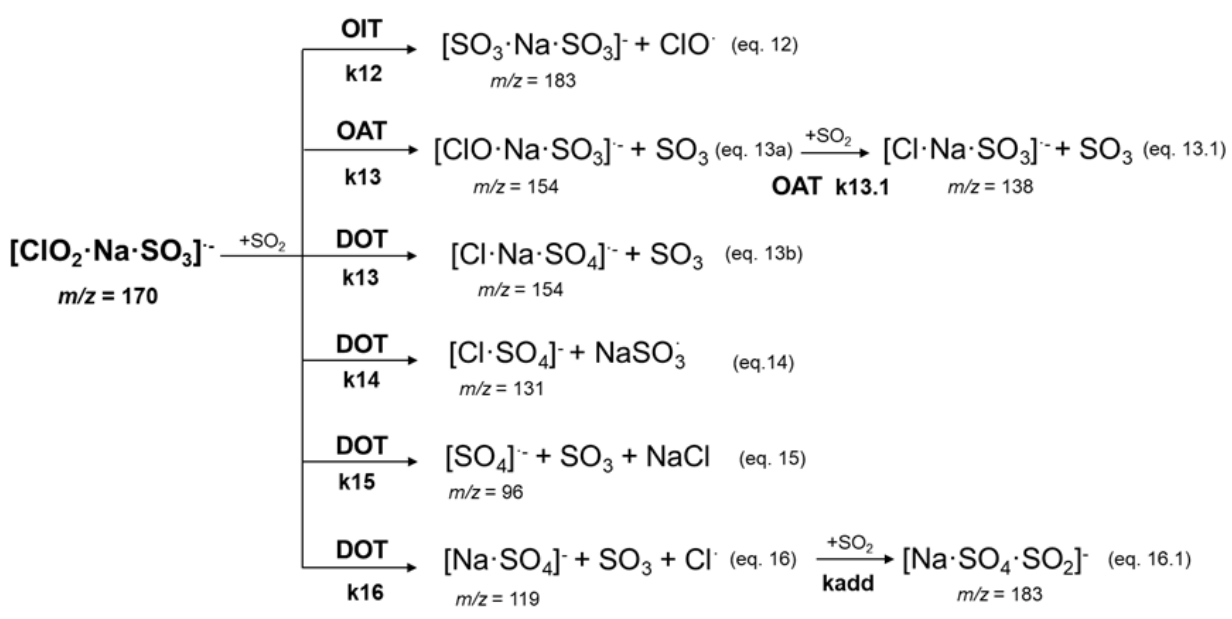

Scheme 3. Reactivity scheme $\left[\mathrm{ClO}_{2} \cdot \mathrm{Na} \cdot \mathrm{SO}_{3}\right]^{\cdot-}$ ions $(m / z=170)$ with $\mathrm{SO}_{2}$. Oxygen transfer channels (OIT, OAT, DOT) and bimolecular rate constants are indicated for each reaction.

The overall reaction shows a rate constant $\left(\mathrm{k}_{\mathrm{dec}}\right)$ of $3.74 \times 10^{-10}( \pm 30 \%) \mathrm{cm}^{3} \mathrm{~s}^{-1} \mathrm{~mol}^{-1}$ and an efficiency of $33.0 \%$ at $298 \mathrm{~K}$ (Table 1). These values agree with those reported for the other $\left[\mathrm{X} \cdot \mathrm{Na} \cdot \mathrm{ClO}_{2}\right]^{-}$parent species analysed and having a unique $\mathrm{ClO}_{2}{ }^{-}$reactive moiety (Table 1). Regarding, instead, the distribution of the three reaction paths, an even more pronounced increase of the DOT channels, accounting for a total amount of $22.7 \%$, was observed (Table 1). The time progress of the reaction is described by the kinetic plot in Figure 5 and the rate constants of each pathway are reported in Table 4. 


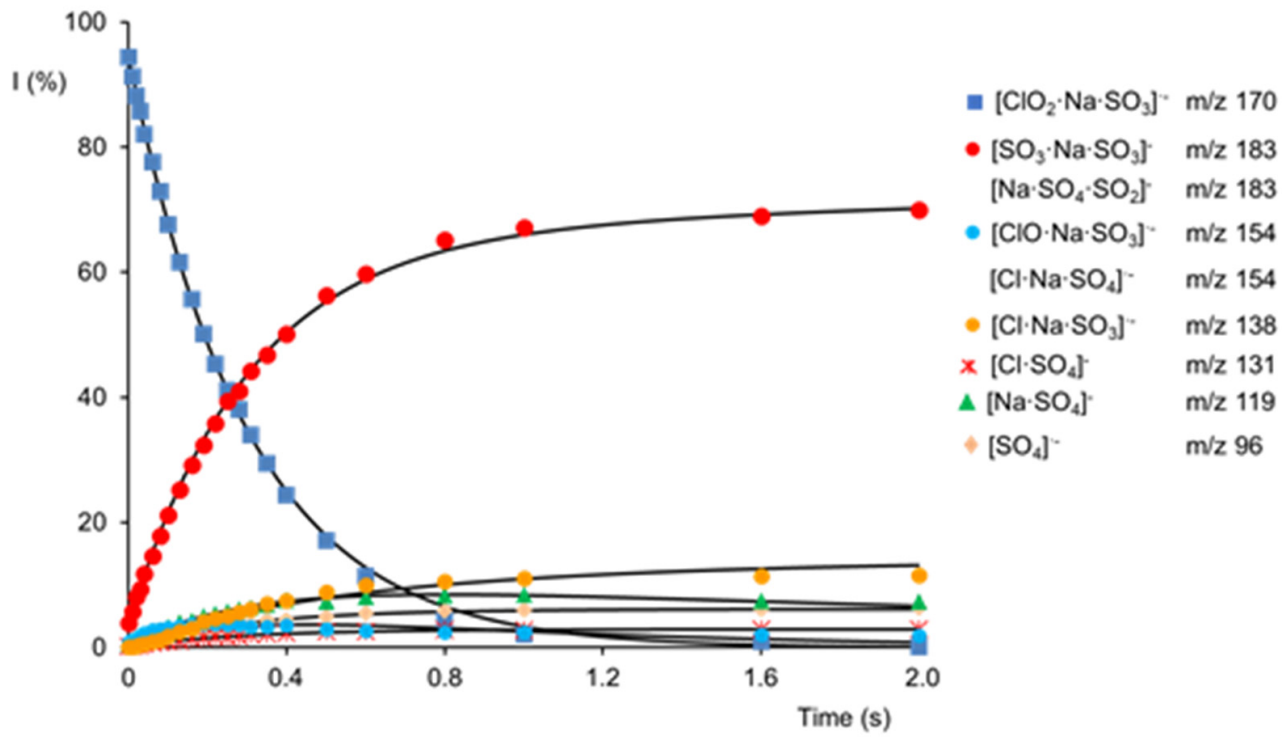

Figure 5. Kinetic plot and best fit lines of the reaction of isolated $\left[\mathrm{ClO}_{2} \cdot \mathrm{Na} \cdot \mathrm{SO}_{3}\right]^{\cdot-}$ ions $(m / z=170)$ with $\mathrm{SO}_{2} . \quad \mathrm{P} \mathrm{SO}_{2}=2.60 \cdot \times 10^{-7}$ Torr. $\quad\left[\mathrm{ClO}_{2} \cdot \mathrm{Na} \cdot \mathrm{SO}_{3}\right]^{\cdot-}\left(\mathrm{m} / z\right.$ 170) $\left(\mathrm{R}^{2}=0.9991\right)$; - $\left[\mathrm{SO}_{3} \cdot \mathrm{Na} \cdot \mathrm{SO}_{3}\right]^{-} /\left[\mathrm{Na} \cdot \mathrm{SO}_{4} \cdot \mathrm{SO}_{2}\right]^{-}(m / z 183)\left(\mathrm{R}^{2}=0.9986\right) ; \cdot\left[\mathrm{ClO} \cdot \mathrm{Na} \cdot \mathrm{SO}_{3}\right]^{\cdot-} /\left[\mathrm{Cl} \cdot \mathrm{Na} \cdot \mathrm{SO}_{4}\right]^{\cdot-}$ $(m / z 154)\left(\mathbf{R}^{2}=0.9686\right) ; \bullet\left[\mathrm{Cl} \cdot \mathrm{Na} \cdot \mathrm{SO}_{3}\right]^{--}(m / z 138)\left(\mathrm{R}^{2}=0.9880\right) ; \times\left[\mathrm{Cl}^{-} \mathrm{SO}_{4}\right]^{-}(m / z 131)\left(\mathrm{R}^{2}=0.9950\right) ;$ $\Delta\left[\mathrm{Na} \cdot \mathrm{SO}_{4}\right]^{-}\left(m / z\right.$ 119) $\left(\mathrm{R}^{2}=0.9973\right) ; \diamond\left[\mathrm{SO}_{4}\right]^{--}(m / z 96)\left(\mathrm{R}^{2}=0.9946\right)$.

Table 4. Rate constants $\left(\mathrm{cm}^{3} \mathrm{~mol}^{-1} \mathrm{~s}^{-1}\right)$ for the reaction $\left[\mathrm{ClO}_{2} \cdot \mathrm{Na} \cdot \mathrm{SO}_{3}\right]^{\cdot-}+\mathrm{SO}_{2}$. Only the most relevant rate constants are reported. OIT: oxygen ion transfer; OAT: oxygen atom transfer; DOT: double oxygen transfer; add: addition reaction.

\begin{tabular}{|c|c|c|c|}
\hline Reactivity & \multicolumn{3}{|c|}{$\mathrm{k} \times 10^{-10} \mathrm{~cm}^{3} \mathrm{~mol}^{-1} \mathrm{~s}^{-1 \S}$} \\
\hline OIT & $\begin{array}{c}\mathrm{k}_{12} \\
2.63\end{array}$ & & \\
\hline OAT & $\begin{array}{c}\mathrm{k}_{13} \\
0.260\end{array}$ & $\begin{array}{l}\mathrm{k}_{13.1} \\
1.09\end{array}$ & \\
\hline DOT & $\begin{array}{c}\mathrm{k}_{14} \\
0.167\end{array}$ & $\begin{array}{c}\mathrm{k}_{15} \\
0.222\end{array}$ & $\begin{array}{c}\mathrm{k}_{16} \\
0.457\end{array}$ \\
\hline $\mathrm{SO}_{2}$ add & $\begin{array}{c}\mathrm{k}_{\text {add }} \\
0.494\end{array}$ & & \\
\hline
\end{tabular}

$\S \pm 30 \%$.

The intracluster OIT process (Equation (12)) proceeds quickly, showing a $\mathrm{k}_{12}$ of $2.63 \times 10^{-10}( \pm 30 \%) \mathrm{cm}^{3} \mathrm{~s}^{-1} \mathrm{~mol}^{-1}$ (Table 4) and leading to the formation of an ion at $m / z$ 183. Unfortunately, the CID mass spectrum of this species does not allow to distinguish between a $\left[\mathrm{SO}_{3} \cdot \mathrm{Na} \cdot \mathrm{SO}_{3}\right]^{-}$or a $\left[\mathrm{Na} \cdot \mathrm{SO}_{4} \cdot \mathrm{SO}_{2}\right]^{-}$structure (Figure S14), the latter already observed as a product of the DOT process involving the $\left[\mathrm{ClO}_{2} \cdot \mathrm{Na} \cdot \mathrm{ClO}_{2}\right]^{-}$parent ion. Nonetheless, based on the reactivity of naked $\mathrm{ClO}_{2}{ }^{-}$and knowing that the $\mathrm{SO}_{3}{ }^{-}$ moiety is notoriously unreactive with $\mathrm{SO}_{2}$, it is reasonable to suppose a $\left[\mathrm{SO}_{3} \cdot \mathrm{Na} \cdot \mathrm{SO}_{3}\right]^{-}$ general formula for this species.

The $\left[\mathrm{ClO}_{2} \cdot \mathrm{Na} \cdot \mathrm{SO}_{3}\right]^{-}$- parent ion is also involved in an OAT reaction proceeding with a $\mathrm{k}_{13}$ of $2.60 \times 10^{-11}( \pm 30 \%) \mathrm{cm}^{3} \mathrm{~s}^{-1} \mathrm{~mol}^{-1}$ and giving rise to an ion at $\mathrm{m} / z 154$ that is consistent with a $\left[\mathrm{ClO} \cdot \mathrm{Na} \cdot \mathrm{SO}_{3}\right]^{\cdot-}$ structure. The consecutive OAT reactivity of this species leading to the ion at $m / z 138$ (Equation (13.1); $\mathrm{k}_{13.1}=1.09 \times 10^{-10}( \pm 30 \%)$ $\mathrm{cm}^{3} \mathrm{~s}^{-1} \mathrm{~mol}^{-1}$, Table 4, Figure S11) accounts for the presence of the surrounding reactive $\mathrm{ClO}^{-}$moiety in $\left[\mathrm{ClO} \cdot \mathrm{Na} \cdot \mathrm{SO}_{3}\right]^{--}(\mathrm{m} / z=154)$. When $\mathrm{MS}^{3}$-isolated into the ion trap by the sequence 170 to 154 and exposed to $\mathrm{SO}_{2}$, the ionic species at $m / z 154$ is only partially reactive towards this neutral gas. A portion of the ionic population at $m / z 154$ survives 
over time, hinting at the concomitant presence of the unreactive $\left[\mathrm{Cl} \cdot \mathrm{Na} \cdot \mathrm{SO}_{4}\right]^{\cdot-}$ species together with the $\left[\mathrm{ClO} \cdot \mathrm{Na} \cdot \mathrm{SO}_{3}\right]^{--}$isobaric ion that is consumed in the consecutive reaction (Figure S15). The $\left[\mathrm{Cl} \cdot \mathrm{Na} \cdot \mathrm{SO}_{4}\right]^{--}$species can reasonably arise from a direct intracluster DOT channel (Equation (13b)), as previously observed in analogous processes involving the $\left[\mathrm{Cl} \cdot \mathrm{Na} \cdot \mathrm{ClO}_{2}\right]^{-}$and $\left[\mathrm{ClO}_{2} \cdot \mathrm{Na} \cdot \mathrm{ClO}_{2}\right]^{-}$parent ions (Equations (3) and (8)). As a result, the $\mathrm{O}_{2}{ }^{-}$transfer from $\mathrm{ClO}_{2}{ }^{-}$to $\mathrm{SO}_{2}$ triggers the release of a neutral $\mathrm{SO}_{3}$ moiety according to the electron affinity values of the species involved in the reaction [27-34,65]. Unfortunately, it was not possible to independently measure $\mathrm{k}_{13 \mathrm{~b}}$, which is therefore included with that of the OAT transfer, $\mathrm{k}_{13}$. As a consequence, the branching ratio of the OAT might be slightly overestimated, at the expense of that for the DOT process, which could therefore be underestimated. Two other DOT pathways reported in Equations (14) and (15) were also previously observed for the $\left[\mathrm{Cl} \cdot \mathrm{Na} \cdot \mathrm{ClO}_{2}\right]^{-}$and $\left[\mathrm{ClO}_{2} \cdot \mathrm{Na} \cdot \mathrm{ClO}_{2}\right]^{-}$parent clusters (Equations (4) and (9), Equations (5) and (10)). All these pathways show rather similar formation rate constants of the $10^{-11} \mathrm{~cm}^{3} \mathrm{~s}^{-1} \mathrm{~mol}^{-1}$ order of magnitude (Table 4).

$\left[\mathrm{ClO}_{2} \cdot \mathrm{Na} \cdot \mathrm{SO}_{3}\right]^{--}$also reacts with $\mathrm{SO}_{2}$, leading to the $\left[\mathrm{Na} \cdot \mathrm{SO}_{4}\right]^{-}$product ion at $m / z 119$ (Equation (16)). The reaction, showing a $\mathrm{k}_{16}$ of $4.57 \times 10^{-11} \mathrm{~cm}^{3} \mathrm{~s}^{-1} \mathrm{~mol}^{-1}$, proceeds with an intracluster $\mathrm{O}_{2}{ }^{-}$transfer. Such unusual reactivity probably involves both the $\mathrm{ClO}_{2}{ }^{-}$anion that triggers a classic $\mathrm{O}_{2}{ }^{-}$transfer and the $\mathrm{SO}_{3}{ }^{--}$moiety that may be responsible for an electron transfer, giving rise to an $\mathrm{SO}_{4}{ }^{2-}$ anion through a concerted rearrangement. As previously reported (Equation (11.1)), the consecutive addition of an $\mathrm{SO}_{2}$ molecule to the $\left[\mathrm{Na} \cdot \mathrm{SO}_{4}\right]^{-}$product ion is observed, thus confirming the identity of the ion at $m / z 119$.

Finally, as to the reactivity of higher species such as $\left[\left(\mathrm{NaClO}_{2}\right)_{\mathrm{n}} \cdot \mathrm{ClO}_{2}\right]^{-}$, only the rate constant relative to cluster with $n=2$ has been measured (Table 1 ), which does not appear to be affected by the number of additional $\mathrm{NaClO}_{2}$ units compared to $\left[\mathrm{ClO}_{2} \cdot \mathrm{Na} \cdot \mathrm{ClO}_{2}\right]^{-}$. However, it was not possible to evaluate the branching ratio of the OIT, OAT and DOT processes of $\left[\left(\mathrm{NaClO}_{2}\right)_{2} \cdot \mathrm{ClO}_{2}\right]^{-}$, due to the low intensity signals relative to parent cluster ions, and to the complex array of peaks resulting from the reaction with $\mathrm{SO}_{2}$.

\section{Materials and Methods}

Mass spectrometric experiments were carried out on an LTQ-XL linear ion-trap mass spectrometer (Thermo Fisher Scientific) that was in-house modified to perform ionmolecule reactions (IMR) [53]. Water-acetonitrile (1:1) solutions of $\mathrm{NaClO}_{2}$ at millimolar concentrations were injected into the ESI (electrospray ionization) source of the instrument at a flow rate of $5 \mu \mathrm{L} \mathrm{min}^{-1}$ via the on-board syringe pump and using nitrogen as sheath and auxiliary gas (flow rate $=11$ and 2 arbitrary units respectively, a. u. $\sim 0.37 \mathrm{~L} \mathrm{~min}^{-1}$ ). Other $\left[\mathrm{ML} \cdot \mathrm{ClO}_{2}\right]^{-}$cluster anions $\left(\mathrm{L}=\mathrm{F}, \mathrm{Br}, \mathrm{I}, \mathrm{ClO}_{3} ; \mathrm{M}=\mathrm{Li}, \mathrm{Na}\right)$ investigated in this work were obtained from millimolar solutions of 1:1 ML and $\mathrm{NaClO}_{2}$ salts dissolved in wateracetonitrile (1:1). To generate chlorite cluster ions and optimize the ion transmission, spray voltage was tuned in the $1.8-3.2 \mathrm{kV}$ range, whereas the capillary temperature was set at $275^{\circ} \mathrm{C}$. The distribution of the ionic aggregates strictly depends on the capillary and tube lens voltage. Hence, these parameters were in turn optimized to increase the signal intensity of the parent ion under investigation.

Once generated, reagent ions were transferred to the vacuum region of the trap, massto-charge isolated and reacted with sulphur dioxide. Each reaction product was then mass selected by a further step of isolation, that is typical of $\mathrm{MS}^{\mathrm{n}}$ experiments performed by Ion Trap mass spectrometers, and the consecutive reactivity of these species was probed towards $\mathrm{SO}_{2}$ to unravel a complete reaction picture. Furthermore, the ionic reactants and products were structurally characterized by collision-induced dissociation (CID) experiments performed by increasing the energy of mass-selected ions in the presence of helium as collision gas (pressure of ca. $3 \times 10^{-3}$ Torr). Depending on the species of interest, normalized collision energies ranging between $20 \%$ and $40 \%$ were typically applied with an activation time of $30 \mathrm{~ms}$. Ions were isolated with a window of $1 \mathrm{~m} / \mathrm{z}$, and the $Q$ value was optimized to ensure stable trapping fields for all the ionic species under investigation. 
Sulphur dioxide was introduced into the trap through a deactivated fused silica capillary that enters the vacuum chamber from a $6.25 \mathrm{~mm}$ hole placed in the backside of the mass spectrometer. The pressure of the neutral gas was kept constant by a metering valve and measured by a Granville-Phillips Series 370 Stabil Ion Vacuum Gauge. Owing to the position of the Pirani gauge, the actual sulphur dioxide pressure was estimated after calibration of the pressure reading [66]. Typical pressures of $\mathrm{SO}_{2}$ ranged between $1.1 \times 10^{-7}$ and $8.0 \times 10^{-7}$ Torr, the uncertainty was estimated to be $\pm 30 \%$. The signals of the ionic reactant and products were monitored over time as a function of the neutral concentration and for each reaction time an average of 10 scan acquisitions was recorded. The normalized collision energy was set to zero and the activation $Q$ value was optimized to ensure stable trapping fields for all the ions. Xcalibur 2.0.6 software was used to acquire all the displayed mass spectra.

All the reactions can be regarded as pseudo-first-order processes due to the excess of neutral gas relative to the reactant ion in the trap. DynaFit4 software package [67] was used to perform nonlinear least squares regression to simultaneously fit reactant and products concentration versus time. Experimental data from the kinetic analyses were fitted to a mathematical model consistent with the postulated reaction mechanism. To check the validity of the kinetic schemes, the obtained unimolecular rate constants were used to simulate the time progress of the reactions using the kinetic simulation function contained in DynaFit4. Bimolecular rate constants $k\left(\mathrm{~cm}^{3}\right.$ molecule $\left.\mathrm{e}^{-1} \mathrm{~s}^{-1}\right)$ were obtained dividing the pseudo-first-order constants $\left(\mathrm{s}^{-1}\right)$ by the concentration of neutral reagent gas. The branching ratios between the three channels (OIT, OAT, DOT) were calculated from the constants of formation of the primary direct products for each reactive species. The reaction efficiency was calculated as the ratio of the bimolecular rate constant $k$ to the collision rate constant $\left(k_{\text {coll }}\right)$, according to the average dipole orientation (ADO) theory [68]. To ensure the accuracy of the $k$ values, approximately 15 independent measurements for each precursor ion were performed on different days over a sevenfold neutral pressure range. The standard deviation in the fitting parameters of the kinetic modelling used is usually evaluated between $10-20 \%$, whereas the uncertainty attached to the measurement of the neutral pressure is typically evaluated $\pm 30 \%$.

\section{Conclusions}

Mass spectrometry has been used to elucidate the gas-phase reactivity of $\left[\mathrm{NaL} \cdot \mathrm{ClO}_{2}\right]^{-}$ cluster anions $\left(\mathrm{L}=\mathrm{ClO}_{\mathrm{x}}{ }^{-}\right.$with $\left.x=0-3\right)$ with sulphur dioxide. These charged species can be taken as simplified models of large-scale reactions occurring in solution or in the flue-gas desulphurization processes, which are accomplished by sodium chlorite solutions.

The kinetic analysis has shown that $\mathrm{SO}_{2}$ was efficiently oxidised by oxygen atom transfer (OAT), oxygen ion transfer (OIT), and double oxygen transfer (DOT) respective to $\mathrm{SO}_{3}, \mathrm{SO}_{3}{ }^{-}$and $\mathrm{SO}_{4}{ }^{--}$. In the case of OIT and DOT processes, an intracluster reaction was observed, by which the oxidised ionic forms of $\mathrm{SO}_{2}$, namely $\mathrm{SO}_{3}{ }^{\cdot-}$ and $\mathrm{SO}_{4}{ }^{\cdot-}$, remain within the cluster and are not released as a free species. The results here reported show that when $\mathrm{ClO}_{2}{ }^{-}$is ligated to a non-redox active molecule, the complexation leads to a moderate reduction in the rate of oxidation processes, without substantially influencing the branching ratio. This effect contrasts, but not surprisingly, with what is observed in solution, where dissolved salts increase the $\mathrm{SO}_{2}$ capture by increasing ionic strength of the solutions. In the gas phase, the direct and strong interaction of the chlorite anion with the ligand is detrimental to the reaction rate. However, the effect of redox active ligands, metallic or metal-free, could be quite different, as suggested by the reactivity observed with $\left[\mathrm{ClO}_{2} \cdot \mathrm{Na} \cdot \mathrm{ClO}_{2}\right]^{-}$, in which the second reactive $\mathrm{ClO}_{2}{ }^{-}$moiety succeeds in increasing the rate of the oxidation. Therefore, the ligation with a redox active group, different from the chlorite one, could succeed in tuning the oxidation processes. 
Supplementary Materials: The following are available online. Figure S1: Full-scan mass spectrum of a $\mathrm{NaClO}_{2}$ salt solution; Figure S2: Ion-molecule reaction between isolated $\left[\mathrm{Cl} \cdot \mathrm{Na} \cdot \mathrm{ClO}_{2}\right]^{-}$cluster ion and $\mathrm{SO}_{2}$; Figure S3: CID mass spectrum of $\left[\mathrm{Cl} \cdot \mathrm{Na} \cdot \mathrm{SO}_{3}\right]^{-{ }^{-}}$ion at $\mathrm{m} / z$ 138; Figure S4: CID mass spectrum of $\left[\mathrm{Cl} \cdot \mathrm{Na} \cdot \mathrm{SO}_{4}\right]^{\cdot-}$ ion at $m / z$ 154; Figure S5: CID mass spectrum of $\left[\mathrm{Cl} \cdot \mathrm{SO}_{4}\right]^{-}$ion at $m / z$ 131; Figure S6: ion-molecule reaction between isolated $\left[\mathrm{ClO}_{2} \cdot \mathrm{Na} \cdot \mathrm{ClO}_{2}\right]^{-}$cluster ion at $m / z 157$ $\mathrm{SO}_{2}$; Figure S7: CID mass spectrum of $\left[\mathrm{ClO}_{2} \cdot \mathrm{Na} \cdot \mathrm{SO}_{3}\right]^{\cdot-}$ product ion at $m / z$ 170; Figure S8: CID mass spectrum of (a) $\left[\mathrm{ClO} \cdot \mathrm{Na} \cdot \mathrm{ClO}_{2}\right]^{-}$product ion at $m / z$ and (b) $\left[\mathrm{Cl} \cdot \mathrm{Na} \cdot \mathrm{ClO}_{3}\right]^{-}$standard ion at $m / z 141$; Figure S9: mass spectrum of the ion-molecule reaction of (a) $\left[\mathrm{ClO} \cdot \mathrm{Na} \cdot \mathrm{ClO}_{2}\right]^{-}$ion at $\mathrm{m} / z$ and (b) $\left[\mathrm{Cl} \cdot \mathrm{Na} \cdot \mathrm{ClO}_{3}\right]^{-}$standard ion at $m / z 141$ towards $\mathrm{SO}_{2}$; Figure S10: mass spectrum of the ionmolecule reaction between $\left[\mathrm{Cl} \cdot \mathrm{Na} \cdot \mathrm{ClO}_{2}\right]^{-}$consecutive product ion at $m / z 125, \mathrm{MS}^{\mathrm{n}}$-isolated from the reaction sequence $m / z 157$ to $m / z 141$ to $m / z 125$ and $\mathrm{SO}_{2}$; Figure S11: magnified plot of the kinetic reported in Figure 4; Figure S12: mass spectrum of the ion-molecule reaction of (a) $\left[\mathrm{Na} \cdot \mathrm{SO}_{4}\right]^{-}$ product ion at $m / z 119, \mathrm{MS}^{\mathrm{n}}$-isolated, and (b) $\left[\mathrm{Na} \cdot \mathrm{SO}_{4}\right]^{-}$standard ion at $m / z 119$ towards $\mathrm{SO}_{2}$; Figure S13: mass spectrum of the ion-molecule reaction between $\left[\mathrm{ClO}_{2} \cdot \mathrm{Na} \cdot \mathrm{SO}_{3}\right]^{-}$product ion at $m / z 170, \mathrm{MS}^{\mathrm{n}}$-isolated from the reaction sequence $m / z 157$ to $m / z 170$ and $\mathrm{SO}_{2}$; Figure S14: CID mass spectrum of product ion at $m / z$ 183; Figure S15: ion-molecule reaction of (a) a mixed ionic population at $m / z 154, \mathrm{MS}^{\mathrm{n}}$-isolated from the reaction sequence $\mathrm{m} / z 157$ to $\mathrm{m} / z 170$ to $\mathrm{m} / z 159$

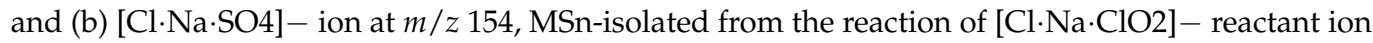
towards SO2; Figure S16: mass spectrum of the ion-molecule reaction between $\left[\mathrm{Na} \cdot \mathrm{SO}_{4}\right]^{-}$product ion at $m / z 119$ and $\mathrm{SO}_{2}$; Scheme S1: Complete reaction sequences of $\left[\mathrm{ClO}_{2} \cdot \mathrm{Na} \cdot \mathrm{ClO}_{2}\right]^{-}$ion at $m / z 157$ and of its product ion $\left[\mathrm{ClO}_{2} \cdot \mathrm{Na} \cdot \mathrm{SO}_{3}\right]^{\cdot-}$ ion at $m / z 170$.

Author Contributions: Conceptualization, A.T. and C.S.; methodology, A.T.; validation, A.T., F.P. and C.S.; Funding acquisition, G.d.P.; investigation C.S.; data curation, C.S.; Supervision G.d.P.; Visualization C.S.; writing—original draft preparation, A.T. and C.S.; writing-review and editing A.T., C.S., F.P. and G.d.P. All authors have read and agreed to the published version of the manuscript.

Funding: This research was funded by Sapienza Rome University "Progetti di Ateneo" (Projects n. RM11816428291DFF, RM11715C81A54060, AR21916B746C06BB). C.S. thanks the Dipartimento di Chimica e Tecnologie del Farmaco, Sapienza Rome University, for a post-doc position within the project Dipartimenti di Eccellenza-L. 232/2016.

Institutional Review Board Statement: Not applicable.

Informed Consent Statement: Not applicable.

Data Availability Statement: Not applicable.

Conflicts of Interest: The authors declare no conflict of interest.

Sample Availability: Samples are not available from the authors.

\section{References}

1. Lima, R.; Bachmann, R.T. Pollutant emissions from modern incinerators. Int. J. Environ. Pollut. 2002, 18, 336. [CrossRef]

2. Vehlow, J. Air pollution control systems in WtE units: An overview. Waste Manag. 2015, 37, 58-74. [CrossRef]

3. Muralikrishna, I.V.; Manickam, V. Environmental Management; Elsevier Inc.: Amsterdam, The Netherlands, 2017.

4. Seinfeld, J.H.; Pandis, S.N. Atmospheric Chemistry and Physics: From Air Pollution to Climate Change, 3rd ed.; John Wiley and Sons: New York, NY, USA, 2016.

5. Dupart, Y.; King, S.M.; Nekat, B.; Nowak, A.; Wiedensohler, A.; Herrmann, H.; David, G.; Thomas, B.; Miffre, A.; Rairoux, P.; et al. Mineral dust photochemistry induces nucleation events in the presence of $\mathrm{SO}_{2}$. Proc. Natl. Acad. Sci. USA 2012, $109,20842-20847$. [CrossRef]

6. Directive (EU) 2016/2284 of the European Parliament and of the Council of 14 December 2016 on the Reduction of National Emissions of Certain Atmospheric Pollutants, Amending Directive 2003/35/EC and Repealing Directive 2001/81/EC.

7. Woodard \& Curran, Inc. Industrial Waste Treatment Handbook, 2nd ed.; Elsevier Inc.: Amsterdam, The Netherlands, 2006.

8. Hu, G.; Dam-Johansen, K.; Wedel, S.; Peterhansen, J. Review of the direct sulfation reaction of limestone. Prog. Energy Combust. Sci. 2006, 32, 386-407. [CrossRef]

9. Koralegedara, N.H.; Pinto, P.X.; Dionysiou, D.; Al-Abed, S.R. Recent advances in flue gas desulphurization gypsum processes and applications-A review. J. Environ. Manag. 2019, 251, 109572. [CrossRef] [PubMed]

10. Zhao, Y.; Guo, T.; Chen, Z. Experimental study on simultaneous desulfurization and denitrification from flue gas with composite absorbent. Environ. Prog. Sustain. Energy 2010, 30, 216-220. [CrossRef] 
11. Adewuyi, Y.G.; He, X.; Shaw, H.; Lolertpihop, W. Lolertpihop, Simultaneous absorption and oxidation of $\mathrm{NO}_{\text {and }} \mathrm{SO}_{2}$ by aqueous solutions of sodium chlorite. Chem. Eng. Commun. 1999, 174, 21-51. [CrossRef]

12. Flagiello, D.; Di Natale, F.; Erto, A.; Lancia, A. Wet oxidation scrubbing (WOS) for flue-gas desulphurization using sodium chlorite seawater solutions. Fuel 2020, 277, 118055. [CrossRef]

13. Chu, H.; Chien, T.-W.; Twu, B.-W. The absorption kinetics of $\mathrm{NO}$ in $\mathrm{NaClO}_{2} / \mathrm{NaOH}$ solutions. J. Hazard. Mater. 2001, B84, 241-252. [CrossRef]

14. Chu, H.; Chien, T.-W.; Twu, B.-W. Simultaneous absorption of $\mathrm{SO}_{2}$ and no in a stirred tank reactor with $\mathrm{NaClO}_{2} / \mathrm{NaOH}$ solutions. Water Air Soil Pollut. 2003, 143, 337-350. [CrossRef]

15. Pourmohammadbagher, A.; Jamshidi, E.; Ale-Ebrahim, H.; Dabir, S. Study on simultaneous removal of $\mathrm{NO}_{\mathrm{x}}$ and $\mathrm{SO}_{2}$ with $\mathrm{NaClO}_{2}$ in a novel swirl wet system. Ind. Eng. Chem. Res. 2011, 50, 8278-8284. [CrossRef]

16. Chien, T.-W.; Chu, H. Removal of $\mathrm{SO}_{2}$ and $\mathrm{NO}$ from flue gas by wet scrubbing using an aqueous $\mathrm{NaClO}_{2}$ solution. J. Hazard. Mater. 2000, 80, 43-57. [CrossRef]

17. Krzyżyńka, R.; Zhao, Y.; Hutson, N. Absorption of $\mathrm{NO}_{\mathrm{x}}, \mathrm{SO}_{2}$, and mercury in a simulated additive-enhanced wet flue gas desulphurization scrubber. Polish J. Environ. Stud. 2010, 19, 1255-1262.

18. Andreasen, A.; Mayer, S. Use of Seawater Scrubbing for $\mathrm{SO}_{2}$ Removal from Marine Engine Exhaust Gas. Energy Fuels 2007, 21, 3274-3279. [CrossRef]

19. Byun, Y.; Hamilton, I.P.; Tu, X.; Shin, D.N. Formation of chlorinated species through reaction of $\mathrm{SO}_{2}$ with $\mathrm{NaClO}_{2}$ powder and their role in the oxidation of $\mathrm{NO}$ and $\mathrm{Hg}^{0}$. Environ. Sci. Pollut. Res. 2014, 21, 8052-8058. [CrossRef]

20. Coelho, F.; Eberlin, M.N. The bridge connecting gas-phase and solution chemistries. Angew. Chem. Int. Ed. 2011, 50, 5261-5263. [CrossRef]

21. Zhu, W.; Yuan, Y.; Zhou, P.; Zeng, L.; Wang, H.; Tang, L.; Guo, B.; Chen, B. The expanding role of electrospray ionization mass spectrometry for probing reactive intermediates in solution. Molecules 2012, 17, 11507-11537. [CrossRef]

22. Fabris, D. Mass spectrometric approaches for the investigation of dynamic processes in condensed phase. Mass Spectrom. Rev. 2004, 24, 30-54. [CrossRef]

23. Troiani, A.; Rosi, M.; Garzoli, S.; Salvitti, C.; de Petris, G. Iron-Promoted C-C Bond Formation in the Gas Phase. Angew. Chem. Int. Ed. 2015, 54, 14359-14362. [CrossRef]

24. Troiani, A.; De Petris, G.; Pepi, F.; Garzoli, S.; Salvitti, C.; Rosi, M.; Ricci, A. Base-Assisted Conversion of Protonated D -Fructose to 5-HMF: Searching for Gas-Phase Green Models. ChemistryOpen 2019, 8, 1190-1198. [CrossRef]

25. Vikse, K.L.; Ahmadi, Z.; Manning, C.C.; Harrington, D.A.; McIndoe, J.S. Powerful insight into catalytic mechanisms through simultaneous monitoring of reactants, products, and intermediates. Angew. Chem. Int. Ed. 2011, 50, 8304-8306. [CrossRef] [PubMed]

26. Gronert, S. Mass spectrometric studies of organic ion/molecule reactions. Chem. Rev. 2001, 101, 329-360. [CrossRef] [PubMed]

27. Domínguez, I.; Frenich, A.G.; Romero-González, R. Mass spectrometry approaches to ensure food safety. Anal. Methods 2020, 12, 1148-1162. [CrossRef]

28. Wang, X.; Wang, S.; Cai, Z. The latest developments and applications of mass spectrometry in food-safety and quality analysis. Trends Anal. Chem. 2013, 52, 170-185. [CrossRef]

29. Cimino, P.; Troiani, A.; Pepi, F.; Garzoli, S.; Salvitti, C.; Di Rienzo, B.; Barone, V.; Ricci, A. From ascorbic acid to furan derivatives: The gas phase acid catalyzed degradation of vitamin C. Phys. Chem. Chem. Phys. 2018, 20, 17132-17140. [CrossRef]

30. Geoghegan, K.F.; Kelly, M.A. Biochemical applications of mass spectrometry in pharmaceutical drug discovery. Mass Spectrom. Rev. 2005, 24, 347-366. [CrossRef]

31. Loos, G.; Van Schepdael, A.; Cabooter, D. Quantitative mass spectrometry methods for pharmaceutical analysis. Philos. Trans. R. Soc. A Math. Phys. Eng. Sci. 2016, 374, 20150366. [CrossRef]

32. Forte, G.; Chiarotto, I.; Giannicchi, I.; Loreto, M.A.; Martinelli, A.; Micci, R.; Pepi, F.; Rossi, S.; Salvitti, C.; Stringaro, A.; et al. Characterization of naproxen-polymer conjugates for drug-delivery. J. Biomater. Sci. Polym. Ed. 2015, 27, 69-85. [CrossRef]

33. Vestal, M.L. The Future of Biological Mass Spectrometry. J. Am. Soc. Mass Spectrom. 2011, 22, 953-959. [CrossRef]

34. Finehout, E.J.; Lee, K.H. An introduction to mass spectrometry applications in biological research. Biochem. Mol. Biol. Educ. 2004, 32, 93-100. [CrossRef]

35. de Laeter, J.R. Mass spectrometry and geochronology. Mass Spectrom. Rev. 1998, 17, 97-125. [CrossRef]

36. Petrie, S.; Bohme, D.K. Ions in space. Mass Spectrom. Rev. 2006, 26, 258-280. [CrossRef] [PubMed]

37. Cacace, F.; Cipollini, R.; DE Petris, G.; Troiani, A. The impervious route to the elusive HOOO ${ }^{-}$anion. Int. J. Mass Spectrom. 2003, 228, 717-722. [CrossRef]

38. Cacace, F.; de Petris, G.; Pepi, F.; Troiani, A. Direct experimental evidence for the $\mathrm{H}_{2} \mathrm{O}^{+} \mathrm{O}_{2}{ }^{-}$charge transfer complex: Crucial support to atmospheric photonucleation theory. Angew. Chem. Int. Ed. 2000, 39, 367-369. [CrossRef]

39. Cacace, F.; de Petris, G.; Pepi, F.; Rosi, M.; Troiani, A. Ionization of ozone/chlorofluorocarbon mixtures in atmospheric gases: Formation and remarkable dissociation of $\left[\mathrm{CHXYO}_{3}\right]^{+}$complexes $(\mathrm{X}=\mathrm{H}, \mathrm{Cl}, \mathrm{F} ; \mathrm{Y}=\mathrm{Cl}, \mathrm{F})$. Chem. Eur. J. 2000, 6, $2572-2581$. [CrossRef]

40. Johnson, G.; Tyo, E.C.; Castleman, A.W. Cluster reactivity experiments: Employing mass spectrometry to investigate the molecular level details of catalytic oxidation reactions. Proc. Natl. Acad. Sci. USA 2008, 105, 18108-18113. [CrossRef] [PubMed] 
41. Johnson, G.E.; Mitrić, R.; Bonačić-Koutecký, V.; Castleman, A. Clusters as model systems for investigating nanoscale oxidation catalysis. Chem. Phys. Lett. 2009, 475, 1-9. [CrossRef]

42. Schlangen, M.; Schwarz, H. Effects of ligands, cluster size, and charge state in gas-phase catalysis: A happy marriage of experimental and computational studies. Catal. Lett. 2012, 142, 1265-1278. [CrossRef]

43. Dietl, D.-C.N.; Troiani, A.; Schlangen, M.; Ursini, O.; Angelini, G.; Apeloig, Y.; de Petris, G.; Schwarz, H. Mechanistic Aspects of Gas-Phase Hydrogen-Atom Transfer from Methane to $[\mathrm{CO}]^{+}$and $[\mathrm{SiO}]^{+}$: Why Do They Differ? Chem. Eur. J. 2013, 19, 6662-6669. [CrossRef]

44. Schlangen, M.; Schwarz, H. Probing elementary steps of nickel-mediated bond activation in gas-phase reactions: Ligand- and cluster-size effects. J. Catal. 2011, 284, 126-137. [CrossRef]

45. Vikse, K.L.; McIndoe, J.S. Mechanistic insights from mass spectrometry: Examination of the elementary steps of catalytic reactions in the gas phase. Pure Appl. Chem. 2015, 87, 361-377. [CrossRef]

46. Vikse, K.L.; Ahmadi, Z.; McIndoe, J.S. The application of electrospray ionization mass spectrometry to homogeneous catalysis. Coord. Chem. Rev. 2014, 279, 96-114. [CrossRef]

47. Troiani, A.; Rosi, M.; Salvitti, C.; de Petris, G. The oxidation of sulfur dioxide by single and double oxygen transfer paths. ChemPhysChem 2014, 15, 2723-2731. [CrossRef]

48. Stewart, I.I. Electrospray mass spectrometry: A tool for elemental speciation. Spectrochim. Acta Part B 1999, 54, 1649-1695. [CrossRef]

49. Hao, C.; March, R.E. Electrospray ionization tandem mass spectrometric study of salt cluster ions: Part 2 Salts of polyatomic acid groups and of multivalent metals. J. Mass Spectrom. 2001, 36, 509-521. [CrossRef] [PubMed]

50. Eberlin, M.N. Electrospray ionization mass spectrometry: A major tool to investigate reaction mechanisms in both solutions and the gas phase. Eur. J. Mass Spectrom. 2007, 13, 19-28. [CrossRef]

51. Castleman, A.W., Jr.; Keesee, R.G. Gas-phase clusters: Spanning the states of matter. Science 1988, 241, 36-42. [CrossRef]

52. Bondybey, V.E.; Beyer, M.K. How many molecules make a solution? Int. Rev. Phys. Chem. 2002, 21, 277-306. [CrossRef]

53. Troiani, A.; Salvitti, C.; de Petris, G. Gas-phase reactivity of carbonate ions with sulphur dioxide: An experimental study of clusters reactions. J. Am. Soc. Mass Spectrom. 2019, 30, 1964-1972. [CrossRef]

54. Shaik, S.; Mandal, D.; Ramanan, S.S.D.M.R. Oriented electric fields as future smart reagents in chemistry. Nat. Chem. 2016, 8, 1091-1098. [CrossRef]

55. Yue, L.; Li, J.; Zhou, S.; Sun, X.; Schlangen, M.; Shaik, S.; Schwarz, H. Control of product distribution and mechanism by ligation electric field in the thermal activation of methane. Angew. Chem. Int. Ed. 2017, 56, 10219-10223. [CrossRef]

56. Geng, C.; Li, J.; Schlangen, M.; Shaik, S.; Sun, X.; Wang, N.; Weiske, T.; Yue, L.; Zhou, S.; Schwarz, H. Oriented external electric fields as mimics for probing the role of metal ions and ligands in the thermal gas-phase activation of methane. Dalton Trans. 2018, 47, 15271-15277. [CrossRef]

57. de Petris, G.; Cartoni, A.; Troiani, A.; Angelini, G.; Ursini, O. Ursini, Water activation by $\mathrm{SO}_{2}{ }^{+}$ions: An effective source of OH radicals. PhysChemChemPhys 2009, 11, 9976-9978. [CrossRef]

58. de Petris, G.; Troiani, A.; Rosi, M.; Angelini, G.; Ursini, O. Selective activation of C-Cl and C-F bonds by $\mathrm{SO}^{+}$radical cations: An experimental and computational study. ChemPlusChem 2013, 78, 1065-1072. [CrossRef]

59. Troiani, A.; Rosi, M.; Garzoli, S.; Salvitti, C.; de Petris, G. Vanadium hydroxide cluster ions in the gas phase: Bond-forming reactions of doubly-charged negative ions by $\mathrm{SO}_{2}$-promoted V-O activation. Chem. Eur. J. 2017, 23, 11752-11756. [CrossRef] [PubMed]

60. Troiani, A.; Rosi, M.; Garzoli, S.; Salvitti, C.; de Petris, G. Sulphur dioxide cooperation in hydrolysis reactions of vanadium oxide and hydroxide cluster dianions. New J. Chem. 2018, 42, 4008-4016. [CrossRef]

61. Troiani, A.; Rosi, M.; Garzoli, S.; Salvitti, C.; de Petris, G. Effective redox reactions by chromium oxide anions: Sulfur dioxide oxidation in the gas phase. Int. J. Mass Spectrom. 2018, 436, 18-22. [CrossRef]

62. Salvitti, C.; Rosi, M.; Pepi, F.; Troiani, A.; de Petris, G. Reactivity of transition metal dioxide anions $\mathrm{MO}_{2}{ }^{-}(\mathrm{M}=\mathrm{Co}, \mathrm{Ni}, \mathrm{Cu}, \mathrm{Zn})$ with sulfur dioxide in the gas phase: An experimental and theoretical study. Chem. Phys. Lett. 2021, 776, 138555. [CrossRef]

63. E Bartmess, J.; Georgiadis, R. Empirical methods for determination of ionization gauge relative sensitivities for different gases. Vacuum 1983, 33, 149-153. [CrossRef]

64. Kuzmic, P. Program DYNAFIT for the Analysis of Enzyme Kinetic Data: Application to HIV Proteinase. Anal. Biochem. 1996, 237, 260-273. [CrossRef]

65. Bowers, M.T.; Su, T. Interactions between Ions and Molecules; Plenum Press: New York, NY, USA, 1975.

66. Van Berkel, G.J.; Kertesz, V. Using the Electrochemistry of the Electrospray Ion Source. Anal. Chem. 2007, 79, 5510-5520. [CrossRef] [PubMed]

67. Linstrom, P.J.; Mallard, W.G. (Eds.) NIST Chemistry WebBook; NIST Standard Reference Database Number 69; National Institute of Standards and Technology: Gaithersburg, MD, USA, 1997. Available online: http://webbook.nist.gov (accessed on 20 October 2021).

68. Tro, N.J. Chemistry, International Edition; Pearson Education Inc.: Upper Saddle River, NJ, USA, 2016; pp. $341-343$. 